\title{
LINGUISTIC DEVIATIONS OF SWARDSPEAK AND ITS IMPLICATION TO GAY STUDENTS' ENGLISH \\ LANGUAGE COMPETENCIES
}

\section{JOY ANN PURAL RUBIALES}

Southern Luzon State University

College of Teacher Education

June 2020 


\section{BIOGRAPHICAL SKETCH}

Name: Joy Ann P. Rubiales

Birthdate: June 26, 1993

Birthplace: Majayjay, Laguna

Permanent Address: Brgy. Suba, Majayjay, Laguna

Contact Number: 0912-568-4020

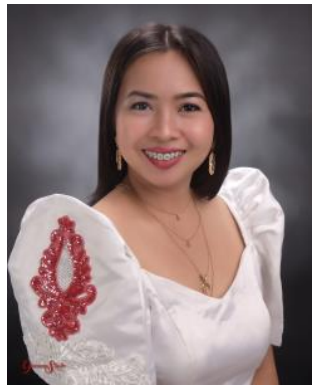

Email Address: joyann.rubiales@ deped.gov.ph

Educational Background:

School/University

Inclusive Years

Suba Elementary School

1999-2005

Majayjay, Laguna

Suba National High School

2005-2009

Majayjay, Laguna

Laguna State Polytechnic University

2009-2013

Sta. Cruz, Laguna

Academic Affiliations:

LSPU Alumni Associations 


\section{CERTIFICATE OF ORIGINALITY}

I hereby affirm that this compliance is my own work and that, to the best of my understanding and certainty, it covers no material previously published by another person nor material to which to a considerable range has been acknowledged for award of any other degree or diploma of a university or other institute of higher learning, except where due credit is made in the text.

I also declare that the logical content of this thesis is the product of my own effort, even though I may have customary assistance from others on style, presentation and semantic expression.

JOY ANN P. RUBIALES

Researcher

JUNE 2020 


\section{DEDICATION}

This self-effacing work is gratefully dedicated to my loving Mom, Analiza Pural

Rubiales and to my Dad, Gaudencio Losanta Rubiales; to my dear siblings

David Jerome and Jimboy; to my supportive special someone Kristoffer

Ryan and to our DEAR LORD, a warmth praises to you all. 


\section{ACKNOWLEDGEMENT}

The researcher would like to express deepest gratitude and sincerest appreciation to the following people who helped in the realization of this study:

Dr. Luis Miguel P. Saludez, research adviser, for the encouragement, support, and valuable assistance in keeping in touch and checking the manuscript and updating for the things needed to follow next, that helped the author to come up with a valid and reliable output through his suggestions and comments;

Dr. Arsenia A. Abuel, panel member and MATE professor, who extended so much time and effort in helping the researcher to the best she can, for being approachable and Dr. Marife S. Magpantay and Prof. Marites M. Roh, oral examination committee, for the consistent effort and support in helping check the manuscript and giving extensive suggestions that helped the author a lot to come up with this study;

Archie M. Condino, Principal I of Suba National High School, for being very supportive to his teachers, especially in this stuff of like this pursuing degree for personal professional growth;

Gaudencio and Analiza Rubiales, parents, for the unconditional love being the constant inspiration to the researcher;

David Jerome and Jimboy, siblings, for their moral support and unceasing encouragement;

Informants, who spared precious time in answering the question and cooperating in the conduct of the study; above all,

God Almighty, the source of all the blessings, for making the researcher blessed as always through His providence, never ending love, and guidance. 


\section{TABLE OF CONTENTS}

Page

Title Page

i

Biographical Sketch

Certificate of Originality iii

Approval Sheet $\quad$ iv

Dedication $\quad$ V

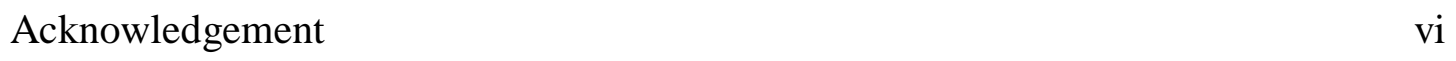

Table of Contents vii

List of Tables $\quad$ ix

List of Figures $\quad$ X

List of Appendices $\quad$ xi

Abstract

Chapter I Introduction 1

$\begin{array}{ll}\text { Background of the Study } & 2\end{array}$

Objectives of the Study 4

$\begin{array}{ll}\text { Significance of the Study } & 4\end{array}$

Scope and Limitation $\quad 5$

$\begin{array}{lr}\text { Definitions of Terms } & 6\end{array}$

$\begin{array}{ll}\text { Chapter II Review of Literature } & 7\end{array}$

$\begin{array}{ll}\text { Theoretical Framework } & 25\end{array}$

$\begin{array}{ll}\text { Research Paradigm } & 26\end{array}$

$\begin{array}{ll}\text { Chapter III Methodology } & 28\end{array}$ 
Research Locale

Informants

Research Design

Instrumentation

Data Gathering Procedure

Data Analysis

Ethical Considerations

Statistical Treatment

Chapter IV Results and Discussion

Chapter V Summary, Conclusions and Recommendations

Summary

Findings

Conclusions

Recommendations

References Cited 


\section{LIST OF TABLES}

Table

Page

1 Linguistic Deviation in Swardspeak in terms of Addition as Spoken by Gay Students

2 Linguistic Deviation in Swardspeak in terms of Change as Spoken by Gay Students

3 Linguistic Deviation in Swardspeak in terms of Creation as Spoken by Gay Students

4 Linguistic Deviation in Swardspeak in terms of Misanalysis as Spoken by Gay Students

5 Implications on the Use of Swardspeak as Identity Marker among Gay Students

6 Implications on the Use of Swardspeak as Self-expression among Gay Students

7 Implications on the Use of Swardspeak as Concealment among Gay Students

8 Implications on the Use of Swardspeak as Softener among Gay Students

9 Implications on the Use of Swardspeak as Emancipation among Gay Students 


\section{FIGURE}

\section{Figure}

Page

1 Input-Process-Output (IPO) Model on the Linguistic Deviations of Swardspeak and Its Implication to Gay Students' Language Competencies 


\section{LIST OF APPENDICES}

Appendix

Page

$\begin{array}{llr}\text { A } & \text { Communication } & 59\end{array}$

B Categories of Responses $\quad 60$

$\begin{array}{lll}\text { C Codes and Transcripts of Interview } & 64\end{array}$

$\begin{array}{lll}\text { D Documentations } & 71\end{array}$ 


\title{
ABSTRACT \\ Title: LINGUISTIC DEVIATIONS OF SWARDSPEAK AND ITS IMPLICATION TO GAY STUDENTS’ ENGLISH LANGUAGE COMPETENCIES
}

\author{
Author: Joy Ann P. Rubiales
}

\section{Adviser: Luis Miguel P. Saludez, Ph.D}

This study aimed to find out the implications of linguistic deviations of swardspeak to the language competencies of the gay students. This research also sought to determine the linguistic deviations in swardspeak used by the gay students; investigate the implications of the use of swardspeak to the language competencies of the students; and develop a sociolinguistic primer on swardspeak and its linguistic deviations. The study made use of qualitative method of research wherein the researcher subjected 12 informants from Suba National High School through recording raw conversations of students using swardspeak. They are officially enrolled as secondary students for the school year 2019 to 2020. The linguistic deviation on the process of using swardspeak depends on the ability of the students. The significant role of creativity and linguistic capability may be developed and improved with frequent use of the language, implications on the use of the swardspeak provide identity for gay students, develop their self-expression, deliver exclusive space through concealment, and find comfort zone using their own language. The proposed sociolinguistic primer on swardspeak and its linguistic deviations is ready for the initial implementation and assessment. The language students might be encouraged in using the language creatively and apply it in the learning process. Activities in terms of speaking can always be practiced in the language learning process to boost the confidence of the students in expressing their ideas. Familiarization of the linguistic deviation categories might be discussed to support the students improve their linguistic competence. Conduct follow up study with the use of swardspeak in a new phase was also recommended.

Keywords: $\quad$ gay students, linguistic competency, linguistic deviation, sociolinguistic primer, swardspeak 


\section{Chapter I}

\section{INTRODUCTION}

Language through instrument inimproving the students' competencies can be used by the society as a means to maintain gender inequality, through power relations, which is both repressive and oppressive. As many users of swardspeak may contribute to the development of a progressive language, it can be a factor to students' competencies fall (Catacutan, 2014). American language scholar Stephen Quakenbush (2015) justified in an interview, aboutPhilippines' rich languages, the increasing use of swardspeak in the society. Swardspeak is something not disturbing, like any other languages, but should be judged based on its effectiveness among its users, and on the way people using it communicate and express their needs. It is difficult for a non-speaker or abeginner but then its intricacies are what make this language unique.

Swardspeak has achieved a higher degree of acceptance in recent years in the Philippines. Both gays and non-gays can be heard uttering gay expressions. But the main role of swardspeak for gay people in the Philippines is to function as an "armor" to shield themselves from chasm and social stigma caused by gender differences (Casabal, 2008).

Though swardspeak acquired such fame and appreciation, it still has its negative sides and certain disadvantages that make it vulnerable to criticisms and apprehensions. On the other hand, the use of swardspeak can be helpful to the language learners in improving their creative minds. Creativity is necessary in all forms of communication. This kind of creativity in using the language is a linguistic deviation (Abbas, 2017).

When a writer wants to make his language to be creative and inventive, he uses the language different from the conventional and everyday language of his day. Using 
unconventional or original language, he can give his readers unexpected surprise and make a strong impression on their mind. This kind of the creative use of language is technically called linguistic deviation, by which he creates original language deviated from the norms of literary convention or everyday speech(Casabal, 2008).

Gay students are recognized in formal institution like school, and swardspeak is another form of language that can be used creatively. The said practice may affect the use of language of the gay's students even inside or outside the school. With the ideas presented, the proponent becomes curious on the relationship of linguistic deviations of swardspeak and its implication to gay students' language competencies.

\section{Background of the Study}

Evident with junior high school student's daily conversation around the school, they use swardspeak intentionally and unintentionally. Students having simple chat with classmates around a hallway during break time to having group activity during classroom discussion. The kind of language they use to convey through speaking might affect the English language learning process and student's language performance.

Languages evolved and in the process of evolution, new words are formed, and others die. There are words that eventually find their way to the mainstream through popular use. This is what happens when words are used occasionally, socially accepted, and later on take part in the written text and even utilized in formal setting. As evident with the country's education system, many learners are engaged in using swardspeak whether gay or straight. This important factor may affect their use of language, the acquisition and process of language development that will improve target competencies (Luistro, 2015). 
It continues to progress as the society takes a step forward for improvement. More so, many languages are being formed and created for different purposes. One of these sub-languages created is the swardspeak, which is basically used by gay men when they are speaking. However, not only the gay homosexuals are the ones that can use this language because even heterosexuals can use swardspeak in their everyday conversations (Gianan, 2008). Language learners undergo the process of acquiring the trend within the society. Scenarios of these languages like swardspeak can dominate the formal language they ought to master.

Through the use of technological innovations of mass communications, people are getting connected to one another. It is also the reason why people are becoming more aware of other cultures and lifestyles (Ayensu, 2013). In this instance, many high school students engagein using swardspeak and acquire language in daily conversation whether in formal or informal setting. Thus, students' performance in language subjects may be affected in this manner.

Gay men in the Philippines, especially those who are out, speak to each other using a colorful language that they invented, mixing English, Tagalog, Visayan, and sometimes even Japanese. Unaware with the language caused confusion and curiosity that triggers the listener to study and try to be familiar. Students who use swardspeak may have reasons like they use swardspeak because they want to avoid having other people hear what they are talking about, especially when it comes to sex. This is also a means of defying the cultural norms and creating an identity of their own.

Standard language is basically an ideal, a mode of expression that seek when wish to communicate beyond immediate community with members of the wider community of 
the nation as a whole, or with the members of the still wider community. As many students try to acquire and use swardspeak on a daily basis, they did not notice that it mixed with their natural language. From this premise, it was decided upon by the researcher to conduct a research using the qualitative methods inlinguistic deviations of swardspeak and its implication to gay students' language competencies within the Junior High Schools in the District of Majayjay Division of Laguna.

\section{Objectives of the Study}

This study aimed to find out the implications of the linguistic deviations of the swardspeak to the language competencies of the gay students.

Specifically, it sought to achieve the following objectives:

1. Determine the linguistic deviations in swardspeak used by the gay students.

2. Investigate the implications of the use of swardspeak to the language competencies of the students.

3. Develop a sociolinguistic primer on swardspeak and its linguistic deviations.

\section{Significance of the Study}

This study would be beneficial primarily to English major students, teachers, school heads, and future researchers on the following respects:

English major students taking up major subjects like language research. This research would serve as a reference in their future discussion in terms of language structure. In addition, the study would serve as a means for the students to appreciate the importance of the new languages formed throughout the years and its relevance to the 
performance of language users. This study could also help students to deeply understand swardspeak and other creoles as component of growing English Language.

Likewise, teachers could also make use of this material in teaching their students in determining the type of linguistic deviation used in different scenarios and its factors similar to swardspeak.

School heads may find the results of the study beneficial as they may develop programs that could be gender sensitive and responsive to the preferences of the students. The output of the study may be recommended for the teachers to be used in any academic activities, thus promoting inclusivity among the learners.

Further, future researchers could make use of this study. The findings of this study could be a reference for future research in the field of language research that deals with gender, swadrspeak, and linguistic deviation.

\section{Scope and Limitations}

The study was limited to exploring the types of linguistic deviations and the investigation of the implications of the use of swardspeak to the language competencies of the students. The study was also confined in the development of the sociolinguistic primer on swardspeak and its linguistic deviations.

Since the study was qualitative by nature, only 12 selected junior high school students around the district of Majayjay Division of Laguna for the school year 20192020 were subjected in the study. The data collection instruments used were the audio recording from which the conversation of participants were captured and the interview protocol. The time frame of this study was from September 2019 to June 2020. 


\section{Definition of Terms}

The terms appearing below were defined both conceptually and operationally to facilitate understanding of the study:

Gay is considered as the third sex after the males and females (Moralista \& Delariarte, 2014). Operationally, it is the gender category of the participants in this study.

Gay Language refers to a form of language that is only peculiar to gay men to facilitate communication among the members with a slight intention of concealing the real message behind the information being expressed (Casabal, 2008). In this study, it is the language modality used by the participants to carry out their conversation.

Gender is operationally a socially constructed definition of women and men. It is not the same as sex (biological characteristics of women and men) and it is not the same as women (Moralista \& Delariarte, 2014).

Language is the function that includes communication, the expression of identity, play, imaginative expression, and emotional release (Robert \& Robins, 2011). In this study, it is a system of conventional spoken, manual, or written symbols by means of which human beings, as members of a social group and participants in its culture express themselves.

Linguistic Deviation occurs when the writer or the speaker chooses not to abide by the rules of his language when he transcends its norms and exceeds the limits of the linguistic protocols that characterize it.

Swardspeak refers to a mix of Tagalog (Pilipino), Spanish, English, and other languages spoken in the Philippines and dates back to at least as early as 1970s. (Manansala, 2003). It is operationally a vernacular language or code used by Filipino gay men. 


\section{Chapter II}

\section{REVIEW OF LITERATURE AND STUDIES}

This chapter presents the related readings and studies on the topic associated with the research problem. The topics presented below discuss facts on types of swardspeak and linguistic deviation.

\section{Swardspeak}

Swadspeak is a term used to describe "overly careful pronunciation, a wide pitch range, high and rapidly changing pitch, breathy tone, lengthened fricative sounds... Also ritual insults, irony, sarcasm, use of sexual and erotic reference, and women-related imagery and metaphor... slang and other new words, mostly relating to aspects of gay and lesbian culture" (Sims, 2014). There are many other expressions that define the same: LGBT speak, LGBT slang, queerspeak, gay slang, homosexual slang, gay language, etc.

Additionally, in the terms of studying the language of LGBT hereinafter, gay speakers, Professor William Leap coined the term "lavender linguistics" (Bobeda, 2012). It concerns the language of non-heterosexual speakers, hence the adjective lavender and not a specific adjectival word for the sexual orientation of the speakers. In parallel, the term "lavender lads" is used repeatedly in 1950s by American Senator Everett Dirksen as a synonymic metaphor for a homosexual (Bailey, 2014).

Since gays were marginalized more than today, at least in developed countries, it was crucial for them to create a language which an outsider will not know about. "Secret languages emerge from situations in which a community feels the need to conceal the content of their utterances from the outside world" and that community is "threatened by 
other communities" (Taylor, 2017). The language ancestor of modern gayspeak is Polari, the underground language, or to be exact, a jargon and a secret vocabulary used not only by homosexuals, but also showmen, criminals, gypsies, men serving in the navy, etc. Since homosexuals were, and still are, but with more equal rights than ever in history, insecure about their lives, especially during the World War II and afterwards, they felt the need to speak in a manner of the "overall structure of a larger language, with a coded lexicon" (Taylor, 2017) to feel more-or-less equal to everyone else, to pass the vital information incognito, and, ultimately, to start to feel more human.

The swarspeak is characterized by an abundance of sex themed expressions and expressions for physical appearance, and intimacy of relationship, rank and eccentricities within the subculture (Hayes, 2016). It was important for gays to keep the language hidden from the majority which resulted in "over-lexicalization of terms for sex, body parts, and people" (Taylor, 2017) and are direct reflections of abstract thoughts based on literal ones. Today, with gays being more and more accepted in society, the domains of interest or, in this case, lexical domains are easier to understand and because of that it is possible to conduct a metaphorical conceptualization.

Swardspeak according to Alba (2016), is the language of Filipino gay men. However, with its current user base, it is not exclusive to the mentioned population. Even women these days are known to have been using swardspeak. The use of swardspeak has become prevalent even among women; those who are referred to as babaeng bakla (Garcia, 2015), also known as fag hag, as early as four decades ago. Aside from this, swardspeak is also adaptive. A set of gay vocabulary is determined by the social class the user belongs to, since many if not all of the words created or modified in swardspeakis 
from another language. Thus, diction is affected by the profession, orientation, principles, or even environment of the Filipino gay individual. Those from with extensive education background and considered part of the upper working class stratum, would have a different set of words used compared to those of the lower strata (e.g. Penicillin and nochikels both pertain to phallus). The spectrum of users of this language based on age also enjoys a wide range just by inference on how the 1970s Philippine societal scenario was teeming and flamboyantly active. But, Garcia may have posited that swardspeak, a sublanguage, "provided gays symbolic purchase into sexuality".

Aside from sex, the other concerns which swardspeak apparently addresses are identity, community-formation, and the outing of someone whom swardspeaker thinks is 'one of the tribe(Garcia, 2008). With this, Garcia may have unconsciously positioned swardspeak under a major, acceptable and accepted language when he added that it is "less an actual language"; thereby solidifying the very structure of oppression that the language is trying to dismantle.

On the contrary, quite on the rise recently is the usage of words in many different media - in film, radio, television, and even in print. Mass media, more particularly television, has been pivotal in the proliferation and dissemination of the words currently being used. The range of terminologies churned out by swardspeakers has become massive and extensive that almost all words can have equivalents or derivatives. Remoto (2010) qualifies this as swardspeak is "continuously updated." It directly negates Garcia's mention of the limited scope of vocabulary swardspeak had, which was, unfortunately more focused on the physical and sexual overtones (Catacutan, 2012). There has been no widely accepted document that details rules in creating terms to be used in swardspeak. 
Although lately, through the technology available these days, there have been attempts by many to list down commonalities and repetitive usages in various instances which may well constitute in the future the Baklarila or Baklang balarila (gay grammar). This absence of accepted rules to form conversational messages in spoken language could possibly be the message content itself. Swardspeak was born into the world to defy the rules that have been set in place to suppress the rights a particular sector of the society. It would then be ironic for the progenitors to use that very same reason - which could be detrimental, counter-ethical, and anachronous. In creating the common tongue among Filipino gay men, the biggest consideration is for the message to be concealed. Tagalog Gay Lingo presents the most common alterations to popular terms, giving birth to a new set of communication pattern (Catacutan, 2012).

As quoted in Castro (2013) in Introduction: Gender, language and translation at the crossroads of disciplines "language is a political act of mediation and communication which either perpetuates or challenges existing power structures within wider social and cultural contexts". The birth of a common language among gays clearly and explicitly defies the culture that the Philippines have had. It had tried to break away from the dualistic perspective of life - heaven and hell, black and white, man and woman. Swardspeak was the weapon that Filipino gay men used to connect with other gays those who are discriminated, oppressed, and ridiculed and belittled.

Swardspeak as a language regards hierarchies as a means to exploit gender. Although arguably, users of gayspeak do not have terms for ditse, sanse, diko, sangko, and bunso. The general term for a male is kuyey and for the female, atey (and its variants, e.g. teh, ateng, acheng). Bakla, baklush, badette can be used interchangeably between the 
two sexes, particularly for female acquaintances. "Language is an example of a control and conditioning factor in the over-all thought of what gender is.

Precedence of masculine over feminine words means dominance and superiority" (Catacutan, 2010) The aforementioned Tagalog words for siblings "employ a hierarchy and distinction to refer to older brothers and sisters. Although some would contend that these show culture of respect, nevertheless, these unconsciously inculcate in individual, submission to the "ruling strata" (Remoto, 2010). In contrast, swardspeak does not look at age and sex as a means to exploit or impose power over another individual.

Language is an oppressive mechanism. Taboo words or terms like regla, which refers to menstruation, is treated as denigrating therefore euphemisms such as dalaw and meron are used instead of the base term which is but natural for any healthy woman of age. Swardspeak is able to send the same message across by using the suffix "-belle" and create reglabelle (or sometimes Regla Bella Torres, a popular Brazilian volleyball player) (Suguitan, 2013). Although some may argue that this may still be a euphemism of the original term, the nature of swardspeak verily proves that the new term for menstruation is common, natural, and acceptable as opposed to base term being regarded as improper and even, unclean. Language as part of culture can be used by society as a means to maintain gender inequality, through power relations, which is repressive and oppressive. In this case, men, because of the patriarchal society, have always had the upper hand.

According to Catacutan (2014) swardspeak is a mode of the many forms of social resistance. How some gays are drag queens, flamboyantly displaying the faux fur and donning makeup of extreme proportions and hues, dressing up like the latest Barbie doll or beauty pageant title holder, swardspeak rebels against the norm of syntactic rules but 
gives heavy emphasis on semantics through shared consciousness and knowledge but more importantly, unconventional pragmatics. The outright intention in the use and origin of swardspeak is to conceal the meaning of the conveyed messages in communications. However, it is also a battle against the norm or the status quo. It does not adhere to strict form, nor does it squarely follow structures which other forms of languages have.

Even in its earlier stages, swardspeak was the essential communication medium Filipino gays used. According to Professor Beth Calinawagan of the UP Department of Linguistics in Diliman, "Tago ang pagiging bakla noon. Gay lingo was their secret code." (Opiña, "Experts trace origins and evolution of gay language") Rightfully, swardspeak can be classified as an argot which according to Gianan (2013), a secret language. Even with its rising popularity these days, swardspeakers, through wit, find new derivations of terminologies in order to conceal the true meaning of messages conveyed.

The term swardspeak was born during a country's darkest days - the Martial law era. Talking bad against the government can put you to jail, or smite you and banish you from the face of the Earth. It was about the same time that the Philippines, in the 1970s, coined the term jeproks and repa (or repapips) by syllable invertion (Tan, "Tagalog slang"). What effected the sprouting of these terms and communication modes could be attributed to the power exerted against free speech. Swardspeak, on that regard is also an underground movement. It destroys the clout of power being brandished to minorities, oppressing those who would speak truth, and gagging the Filipinos preventing them to communicate efficiently and freely. Further, it "reflects the experiences and historical oppression of gay Filipino men” (Manalansan, 2013).

Swardspeak has been using this mode to express their ideas. From the time that freedom of expression has regained its footing in the Philippines after 1986 revolution, a 
lot has already been founded. From the 80 s to the early years of 2000 s, two shows have been created by Philippine television network GMA-7 which catered to gayspeak Giovanni Calvo's Katok mga Misis and Out - both of which had segments that dedicated to explaining the meanings and etymologies of gay terms. These shows have made the swardspeak experience transcend into national awareness by means of mass media. In the more recent years, Vice Ganda of Showtime was able to concoct terms that have gained national scope and usage with anyare and ansaveh, to name a few (Racoma, 2013).

This mode of expression has become pervasive, able to migrate from spoken to written and now to hypertext. Compendiums or lexicons of gay terms abound in many sites in the Web. In the popular social networking site Facebook, BEKINARY - The BEKIMON dictionary lists gay terms along with its meanings, some with etymologies. Aside from this, the owner of the account has also uploaded videos in Youtube (bernjosep), starting three years ago, with a couple of them breaching the 100,000 hits mark. Aside from these, the Filipino gay individual has taken steps to celebrate his coming out by recreating himself or his works in the virtual world. Bloggers abound, many of them becoming "avenues for a more entertaining discussion on gayspeak. These bloggers are gatekeepers and progenitors of gayspeak; they maintain the sanctity of their own craft ... as well as contribute to the development of this language" (Casabal, 2008).

The Filipino gay rhetoric, from being a common tongue among many parloristas and baklang halimaw or tarat, has been slowly introduced into mainstream Filipino usage through different media. It has successfully, though not completely, hurdled waves of discrimination. It has transformed from one medium of communication to another, able to adapt to challenges technologies have ushered us in. With Bekimon and other sites, 
'professing' and using it online for various purposes, in different platforms, swardspeak is here to stay - everything that ever was - available forever (Catacutan, 2012).

Swardspeak uses the elements from Tagalog, English, Spanish, and some from Japanese, as well as celebrities' names and trademark brands, giving them new meanings in different contexts. It is largely localized within gay communities, making use of words derived from the local languages or dialects, including Cebuano, Hiligaynon, Waray, and Bicolano (Salao, 2010).

A defining trait of swardspeak slang is that it more often than not immediately identifies the speaker as homosexual, making it easy for people of that orientation to recognize each other. This creates an exclusive group among its speakers and helps them resist cultural assimilation. More recently, though, even non-members of gay community use this way of speaking, particularly heterosexual members of industries dominated by gays, such as the fashion and film industries.

By using swardspeak, Filipino gays are able to resist the dominant culture of their area and create a space of their own. The language is constantly changing, with the old phrases becoming obsolete and new phrases frequently entering everyday use, reflecting changes in their culture and also maintaining exclusivity. The dynamic nature of the language refuses to cement itself in a single culture and allows for more freedom of expression among its speakers. Words and phrases can be created to react to popular trends and create alternatives to the strictly defined lifestyle. By these characteristics, swardspeak creates a dissident group without any ties to the geographical, linguistic, or cultural restrictions, thus allowing its speakers to shape the language as appropriate to the times. In this way, the languages are not only "mobile" and part of a larger community, but also open to more specific or local meanings. (Sunguitan, 2010). 


\section{Linguistic Deviation}

According to Oliver Twist in his study about Linguistic Deviation, when a writer wants to make his language to be creative or inventive, he uses the language different from the conventional and everyday language of this day. Using unconventional pr original language, he can give his readers unexpected surprised and make a strong impression on their mind. This kind of the creative use of language is technically called linguistic deviation, by which he creates original language deviated from the norms of literary convention or everyday speech. G. N. Leech, in a Linguistic Guide to English Poetry, explains linguistic deviation with the concept of foregrounding.

Based on the study of Real English Journal on March 2015, the importance of linguistic deviation due to its being motivated breach of the rules, it has a purpose and a function. Writers especially poets resort to/ turn to deviation to achieve certain artistic aims and effects as Leech say " a poet may transcend the limits of the language to explore and communicate new areas of experiences Through deviation a poet can communicate unique experiences which he feels cannot be effectively communicated by means of the normal communicative resources of his tongue (his native normal language). Speaker may also deviate to realize specific effects on the reader by striking him with something unexpected forcing him to focus his attention on the deviant sequences. Deviation which is a linguistic phenomenon has an important psychological effect on the readers (or hearers ). If a part of a poem is deviant, it becomes especially noticeable, or perceptually prominent. This is called "foregrounding" (Short 2004).

The term 'language' here, is used not as a constructed language with its own grammar, syntax, morphology and phonology, but in the same way as linguists would 
discuss women's language (Cage, 2009), as a way of speaking, a kind of socialist. Older studies in Queer Linguistics, such as Legman's The Language of Homosexuality: An American Glossary, focused purely on Lavender Lexicons in the form of a dictionary (Kulick, 2000), rather than including more holistic view which necessitates simultaneous study of the gay culture in which the lexicon is being used.

\section{Language and Gender}

It is not just important to study gender differences in language to identify the differences and to better understand the other sex, but because it also holds an important place in feminism and women's history. According to Talbot, there are two (2) views regarding the relationship between language and gender. First, and what she feels is the weaker view, is that language reflects society. So for example the use of "Miss" and "Mrs" as a distinction of marital status for women reflects how this is an important distinction for a woman (as opposed to a man, who uses only "Mr" no matter what the marital status). The other and stronger view according to Talbot (2007) is that language creates gender divisions instead of simply reflecting the divisions. So the use of "Miss" and "Mrs" do not just reflect society but create and sustain inequality. Feminists then have an interest in this inequality that language either reflects or creates in sustaining gender divisions (McDonald, 2011).

Differences in the ways that men and women use language have long been of interest in the study of discourse. Despite the extensive theorizing, the actual empirical investigations have yet to converge on coherent picture of gender differences in language. A significant reason is the lack of agreement over the best way to analyze language. In 
this research, gender differences in language use were examined using standardized categories to analyze database of over 14,000 text files from 70 separate studies. Women used more words related to psychological and social processes. Men referred more to object properties and impersonal topics. Although these effects were largely consistent across different contexts, the pattern of variation suggests that gender differences are larger on tasks that place fewer constraints on language use (Pennebaker, 2018).

According to Mustapha (2013), it is interesting to note that the concern about gender in language education studies (in learning materials and environment) that started not many years ago has grown so large and results of the undertakings have not only impacted on the educational sector but also on society at large with the attendant outcome of empowering women for national development in some countries. Government bodies and international and non-governmental organizations recognize the contributions these studies make and have been funding research in the area with follow -upactions that have made tangible contributions to development.

Since most studies are scattered in journals, monographs and websites, a handy textbook of collection of materials/studies from various countries might be a welcome idea in the near future. Gender in learning materials should continue in under-researched sites just as studies on talk around the text should follow text studies. However, the impact of sexist and progressive texts should also be examined together with the uptakes of stakeholders on text and talks. Bar-placing on methods (data collection and analysis) might not be necessary if we are to promote flexibility that will create the atmosphere for robust research (Mustapha, 2013).

There is a number of close relationships between Gender and language. Another word, men's way of using language and women's way of using language is different. It is 
because of structure of the language, norm of the society or people of the society who use the language. Moreover, gender (male-female) is socially constructed. Because of the social institution or taboo, variations/differences are found between men and women. In addition to men's style of speaking and women style of speaking are deeply rooted in power structure. In addition, the personality of the individual and the vitality of the group are also involved in the explanation of variability in language use. Therefore, there is a close connection between the structures, vocabularies and the ways of using language and the social roles of men and women who speak the language (Shazu, 2014).

Nguyen (2014) stated that sexist language and language discrimination are the important issues that exist in every language and need to be solved so that society's sexist attitudes can be changed, which leads to the fact that men and women are treated equally in language and in all fields of society. Through many studies, power in gender language has been proven to be present in language. English and Vietnamese are two languages with different features related to cultures, people. However, these two languages have some similarities in the relationship between gender and language, especially the issues of power in gendered language. In Vietnamese society nowadays, men and women are equal. Therefore they have a right to make the language less sexist. Yet, according to Wardhaugh (2010, p.354), "it may be utopian to believe that language use will ever become 'neutral'. Humans use everything around them - and language is just a thing in that sense - to create differences among themselves."

Xia (2013) believed that with the development of society, there will be fewer differences in the usage of language. Language, as a tool of human communication, will be improving day by day, and this needs the effort of both men and women. "The 
establishment of women's studies"e initiatives developed from this sense of women's commonality as well as from the realization that women were excluded from large parts of public and academic life" (Flotow, 2014). With more participation into the social life, business, academic field and so on, there will be other changes in the future. The changes in the language can show the improvement in women's social status.

There are several aspects where language may power the authorization of women's language at the expense of men. Morgan (2016) had drawn an example in the characterization of a country as "she" and in expressions of "mother tongue". These illustrate that women have significant position and responsibility in society. In Shona language, this perception of woman as polar also contributed to the issue of women's authorization, such as musha mukadzi, an expression that expressing women as the most vital components at home; vakadzi ndivo vachengetedzi vetsika dzedu, an expression that suggested women as the protector of the norms and values. On the other hand, some terms and expressions show manifestation that authorized men at the expense of women.

As an illustration, Goddard and Patterson (2010) identified term like "bachelor" and "spinster" refers to "unmarried adult male" and "unmarried adult female". Explicitly, "bachelor" connotes a man who preferred to stay single; in contrast "spinster" connotes a woman who has been unsuccessful in finding a spouse. In chiShona, when one give birth to a girl, elders will say "hwakovanwa wafa woga wafa woga" meaning "now life has been divided each can die alone", implying that the girl will get married and leave the house. On the contrary, when one gives birth to a boy, the elder will say "makorokoto musha wakura" meaning "congratulation, the home has grown; it implies that men have greater value than women (Isaac, 2008). 
According to Paula (2010), she identifies that gender system has altered greatly and provide explanation for why the alterations were uneven. These changes occurred since 1960 s and identified as "a revolution". There were several indicators causing these changes. The author argues that in reduction of female activities and jobs, there were few cultural or institutional changes, and as consequence, women possess greater inducement than men to proceed to gender-non-traditional activities and perspectives.

The changes in reduction of "female" activities and asymmetric inducements for men and women affected by education. The current study found that in 16 developed countries in 2000 , the women with more education were more likely to be hired. For instance, data in USA in 1970, $59 \%$ of college graduated women, but only $43 \%$ women with less than high school education were hired. In 2007, the estimation increased to $80 \%$ for college graduated and $47 \%$ for less than high school education.

"Regarding gender, extensive research on language, culture, and identity has sought to uncover 'the logic of the encoding of sex differences in languages,' to analyze 'oppressive implications of ordinary speech,' to explain miscommunication between men and women, to explore how 'gender is constructed and interacts with other identities,' and to investigate 'the role of language in helping establish gender identity [as] part of a broader range of processes through which membership in particular groups is activated, imposed, and sometimes contested through the use of linguistic forms... that activate stances' (Duranti 2009).

Other work explores how language is used to reproduce, naturalize, and contest gender ideologies, drawing from disciplinary perspectives... Critical discourse, narrative, metaphor, and rhetorical analysis have been used to examine other gendered dimensions 
of processes of meaning making, such as gender bias in cell biology and factory farm industry language used to conceal violence (Beldecos et al. 2018; Glenn, 2014).

\section{Gender}

From a postmodern perspective and acknowledging the contributions of scholars such as Butler and Foucault, gender is understood as a sociocultural category by which the issue of the body is connected to the everyday social and cultural practices and discourses. Litosseliti (2016) describe gender as the social behaviors, expectations, and attitudes related to beingmale and female; she asserts that the features that have been designated to the sexual difference are cultural constructions, socially determined and alterable. Yet, for the design of the course, and with the objective of understanding gender inequities in education and the possibilities for transformation, we positioned this social category as “discourses of multiplicities” (Castañeda-Peña, 2009).

This pluralistic vision promotes the idea that "there is not a particular masculinity, but masculinities; and there is no single femininity, but femininities both masculinities and femininities constitute and reconstitute subjects establishing permanently changing asymmetrical relationships in contexts where they participate" (Castañeda-Peña, 2009). Understanding gender as "discourses of multiplicities" helps address the normalization of differential discourses and the endorsement of explicit and tacit ideas that cause gender inequalities. In other words, centering understanding of this category from a dualist and essentialist view of male/female, masculinity/ femininity, or girls/boys, can be avoided which favors the production of the rigid, fixed, hegemonic, and is often discriminatory connotations of how the genders should be or act. 
This vision of gender, among other issues that were part of the course, would eventually give some tools to understand language learning as a socializing process for construction of gender subjectivity and production of gendered rules, relations, practices, and representations in the setting of their language classrooms (Litosseliti, 2016).

Language competencies are important for teaching and learning in the higher education as they determine how wellstudents will be able to understand and critically analyze knowledge pertaining to their subject. The results of the study suggest that university lecturers and students differ significantly in their implicit beliefs about e students' English language competencies. Such discrepancy could hamper academic achievements in higher education. Owing to their beliefs, lecturers may underestimate students' language competencies and, therefore, lower their expectations while students may overestimate their language competencies and, therefore, see no need for improving their language skills, all of which is likely to negatively affect academic standards. In the long run, opposing beliefs among lecturers and students may compromise learning experience and their academic and professional success, (Otaala \& Plattner, 2013).

According to Reyaz (2016), humans are unique and so is culture. Humans behave differently when there is a change in the environment and so is the case that when the cultures alter, the way of using language, or better still, the way one talks, alters as well. In some cultures, posing direct question is considered rude, while in other sitting together in silence, without talking, is a norm. These alterations comprise differing interpretations of varied speech components that apply across cultures. Dell Hymes, an anthropologist, urged that there should be a comparative study of speaking, which he called ethnography of communication. The paper would try to analyze the idea that being able to speak one's 
native language error-free in terms of grammar does not imply that one is competent in the language, but it should also be noted that having a good grasp of the social norms is equally important, if not more important, as well. Also, the paper would focus on Hymes' analytical framework which helps in analyzing the language without much cultural bias. Genres; is intended by him as universal characteristics of speaking.

As cited by Rozman (2015) Dell Hymes is best known for his founding role in introducing the concept of Ethnography of Communication (EOC) in the late sixties which regards by him as an "active action of humanway of life" (Hymes, 2011). Aimed to describe the new approach to understanding language in use, the concept previously proposed as ethnography of speaking, later amended to ethnography of communication (Johnstone \& Marcellino, 2010). Through the communication process, Hymes tried to understand the society and the ethnic group's culture and laterdeveloped a framework of “Speaking Model” (Ray \& Biswas, 2011).

According to Small (2008), the framework is designed "to describe in complete detail different genres of speech in order to understand what real communication is and what rules,linguistic or otherwise, make a speaker, competent" (Small, 2008). Purposely designed to explore the notion of communicative competence among participants, the framework aims tostudy the language use in the human daily life displayed by particular speech communities (Newmeyer, 2014). Hence, it is one of the approaches implemented to understand the societies and their respective cultures and reconstruction of an ethnic group in particular and nation in general.

Ray and Biswas in 2011 stated that, the EOC specifically relates the ethnography withthe language, in which serves as a "qualitative method in the field of communication 
as well as cultural anthropology" (Ray \& Biswas, 2011). Littlejohn and Foss (2015) reminds that Hymes originally suggests that "cultures communicate in different ways, but all forms of communication require a shared code..." as cited in Inayah (2009). The framework largely conceptualizes communication as a continuous flow of information; hence the communicators need to know the code, setting, message form, topic, and event to effectively transmit the messages (Lindlofand \& Taylor, 2002).

According to Inayah (2009), the SPEAKING Model developed by Hymes can be applied to many sorts of discourse which consist of altogether sixteen components which is message form; message content; setting; scene; speaker/sender; addressor; hearer/ receiver/audience; addressee; purposes (outcomes); purposes (goals); key; channels; forms of speech; norms of interaction; norms of interpretation; and genres. In order tofacilitate the representation of this criterion, Hymes grouped the sixteen components within eight (8) divisions which are: setting and scene, participants, ends, acts, keys, instrumentalities, norms and genre.

As mentioned by Bagaric (2007) in his journal Defining the Communicative Competence, Canale and Swain (1980) and Canale (1983) understood communicative competence as a synthesis of an underlying system of knowledge and skill needed for communication. In their concept of communicative competence, knowledge refers to the (conscious or unconscious) knowledge of an individual about language and about other aspects of language use. According to them, there are three (3) types of knowledge: knowledge of underlying grammatical principles, knowledge of how to use language in a social context in order to fulfill communicative functions and knowledge of how to combine utterances and communicative functions with respect to discourse principles. In 
addition, their concept of skill refers to how an individual can use the knowledge in actual communication. According to Canale, skill requires a further distinction between underlying capacity and its manifestation in real communication, that is to say, in performance.

\section{Theoretical Framework}

"Language does change, and it is just as impossible to preserve the tongue that Shakespeare spoke as it is to stop cultural change" (Crystal, 2012). For Murtiana (2012) language change is a phenomenon in which language features like phonetic, lexis, syntax, and semantic vary as a result of thechanging needs. As a language used by many people throughout the world, English has undergone a series of fascinating changes since the era of Old English until now. The English expressions which hundred years ago were considered simple and colloquial might seem strange to today's generation.

Language is dynamic. Language is never static, it is dynamic which goes on changing. Language occupies an important place in the lives of human beings. Language is the very medium of expression. The everyday activities of life are sure to come to an end unless language functions as a means of communication. Language is inextricably tied up with the social and cultural evolution of mankind. Language is as familiar to us as the air we breathe or the saliva that we carry in our mouth. So we are hardly conscious of its significance. However, effects of language are most remarkable. It is in fact language that distinguishes human beings from the animals. Barber rightly remarked "language is the most remarkable tool that man has invented and is one that makes all other possible" (Drakakis \& Liebler, 2014). 
Language processing is traditionally assumed to involve a lexicon, which is the repository of facts concerning individual words, and a set of rules which constrain the ways those words can be combined to form sentences. From the point of view of a listener attempting to process spoken language, the initial problem involves taking acoustic input and retrieving the relevant word from the lexicon. This process is often supposed to involve separate stages of lexical access (in which contact is made with candidate words based on partial information), and lexical recognition (or retrieval, or selection; in which choice is made on specific word), although finer-grained distinctions may also be useful (Tyler \& Frauenfelder, 1987). Subsequent to recognition, the retrieved word must be inserted into data structure which will eventually correspond to a sentence; this procedure is assumed to involve the application of rules (Elman, 2011).

The fact that language is dynamic should be treated wisely by its users by being aware of appropriate situation in which particular language feature should be applied. In the context of English teaching and learning, it is the role of teacher to expose students to different varieties of English, spoken andwritten, formal and informal. Teachers should also be able to make students aware about appropriate and inappropriate English, so they know how to use the language appropriately in particular context (Murtiana, 2012).

\section{Research Paradigm}

Figure 1 on the next page shows the Input-Process-Output model on linguistic deviations of swardspeak and its implication to gay students' language competencies. The input frame shows the following: the types of linguistic deviations in swardspeak used by the gay students, their English language performance in a class, and relationship between 


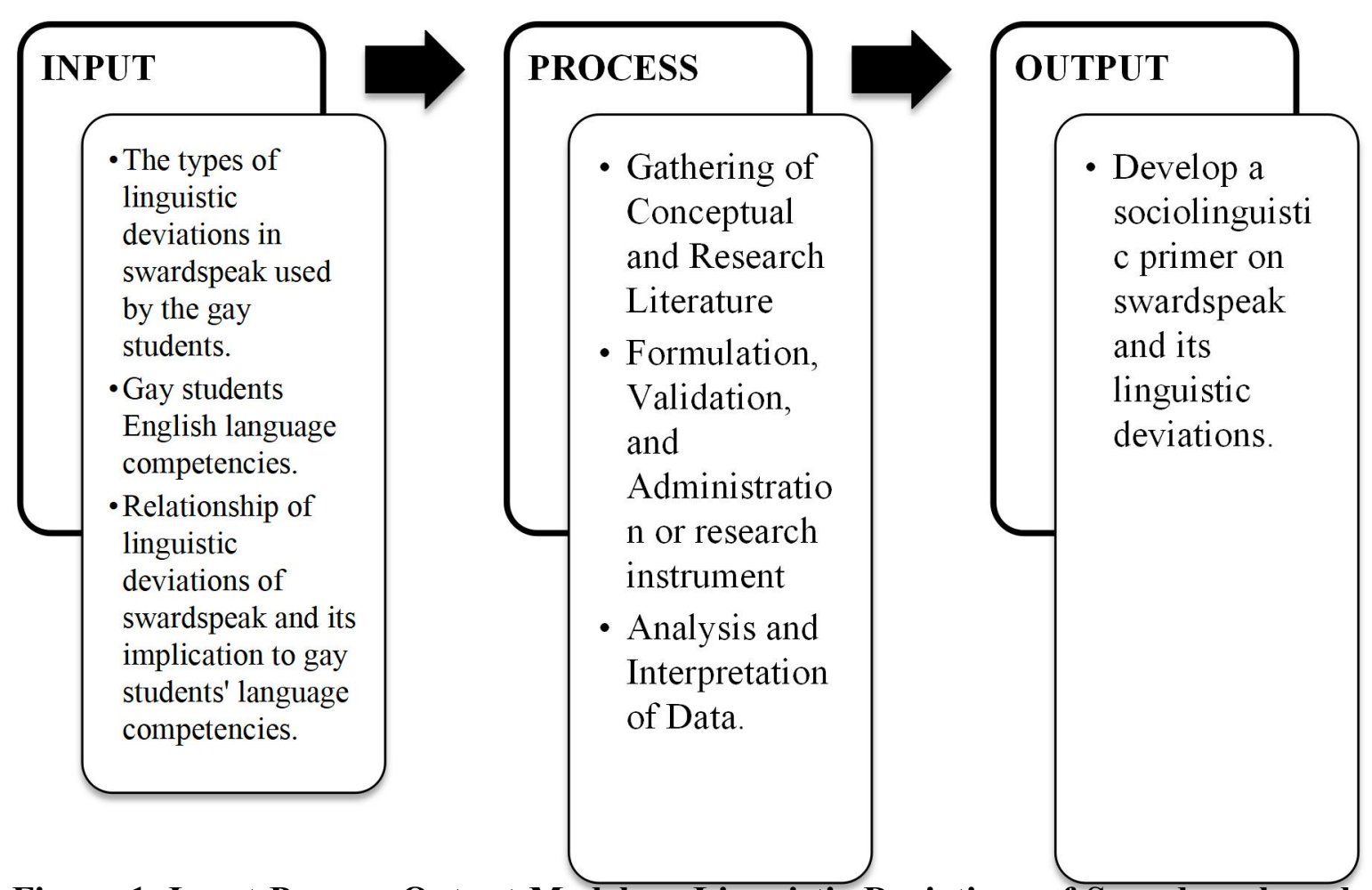

Figure 1. Input-Process-Output Model on Linguistic Deviations of Swardspeak and Its Implication to Gay Students' Language Competencies

the types of linguistic deviations and the English language performance of gay students. The process frame indicates the steps by which the study will be conducted. The steps are as follows: gathering of conceptual and research; literature formulation, validation, and administration or research instrument; and analysis and interpretation of data

The output frame displays the outcomes or dependent variables of the study which include developing a sociolinguistic primer on swardspeak and its linguistic deviations. 


\section{Chapter III \\ METHODOLOGY}

This chapter provides the research design and statistical treatment used in the study. Likewise, this identifies the respondents and the sampling techniques employed. Validation techniques for instrument and data gathering complete the procedures utilized.

\section{Research Locale}

This study was conducted at the Suba National High School in the District of Majayajay, Division of Laguna wherein many students use swardspeak on their daily conversation whether inside or outside the school premises. The selected high school students resorted out of the subjects' willingness to cooperate in the conduct of the study.

\section{Informants}

The informants of the study were 12 high school students from Suba National High Schoolof Majayajay in the Division of Laguna. They were officially enrolled as secondary students for the academic year 2019 to 2020. The informants were chosen purposively since the study was primarily focuson the types of linguistic deviations engagedin using swardspeak. This is the reason that they are the ones who can give a clear picture of how swardspeak really affect their English language competencies.

\section{Research Design}

The qualitative method of research was used in this study. It was employed to gather information about the present existing condition of the study. It also dealt with the 
process of determining, and identifying the types of linguistic deviation each secondary student used. Data were gathered through recorded conversations of the students who use swardspeak. The phases of these process include the transcribing of recordings and identifying analysing the linguistic deviation category.

\section{Instrumentation}

The researcher utilized a recording of raw conversations of high school students using swardspeak. The recorded conversation as the gathered data were transcribed, categorized to its respective linguistic deviations and then analysed and interpret. To investigate the implication of the swardspeak to students' language competencies, the researcher provide simple question to the informants. Data from the informants were analyzed and categorized, then afterwards interpreted.

\section{Data Gathering Procedure}

The study was concerned with implications of linguistic deviations of swardspeak to the language competencies of the gay students. The researcher secured approval letter before she conducted her study. After securing letters needed, permission from research adviser was sought to execute the process.

The conduct of the recording of raw conversation with the willingness of the respondents were scheduled. These substantiated the needed information for the study. Recording of raw conversation were transcribed and analyzed and the results of the study were presented using the quantitative method. The analysis and interpretation of gathered data followed. 


\section{Analysis of Data}

For qualitative data analysis, Mulaudzi (2016) mentioned in his study that the qualitative data should be analyzed primarily in an inductive manner which involves organizing data into categories and identifying patterns among the categories. The process of data analysis involves preparing data for analysis, conducting the different analysis, moving deeper and deeper into understanding of the data, representing the data, and interpreting the larger meaning of the data. Data were presented in narrative form bearing the detailed information on how linguistic deviations of swardspeak have its implication to gay students' language competencies within the Suba National High School District of Majayjay Division of Laguna.

\section{Ethical Consideration}

Ethical considerations are essential in research particularly in qualitative research context, as researchers are in a powerful position when interpreting participant's words (Steffen, 2016). This study followed the core ethical principles that are important in qualitative research. The first principle includes respect for persons where the researcher respects the autonomy, decision-making and dignity of the participants either external or internal stakeholders. The second principle is about beneficence that is, minimizing the risks (physically, psychologically and socially) and maximizing the benefits to research participants. The third principle is justice, in this study participants were selected from groups of people whom research benefits. The last principle is respect for communities, the researcher protect and respect the values and interests of the community as a whole and protect the community from harm considering the selected barangay school used in 
this study. In addition, all the participants were involved in their own free will and they agreed to be participated during their free time. The confidentiality and anonymity of the participants and their respective schools were also protected.

\section{Statistical Treatment}

The responses of the study were treated and analyzed using frequency count and its percentage.

Frequency Count. This non-parametric tool was used to describe the number of times a specific swardspeak was used.

Percentage. It was used to identify the most use swardspeak on the gathered data.

$$
\mathrm{P}=\frac{\text { Frequency }}{\text { Total number of responses }} \times 100
$$




\section{Chapter IV}

\section{RESULTS AND DISCUSSION}

This chapter includes the presentation, analysis, and interpretation of the data drawn from the process of identifying the swardspeak used according to its respective linguistic deviation. The data are presented in tabular form which shows the computation of the data gathered for better understanding of the readers.

\section{Linguistic Deviations in Swardspeak Used by the Gay Students}

Table 1. Linguistic Deviation in Swardspeak in terms of Addition Spoken by Gay Students

\begin{tabular}{|l|c|c|l|}
\hline \multicolumn{1}{|c|}{ Category } & Frequency & Percentage & \multicolumn{1}{|c|}{ Exemplar } \\
\hline $\begin{array}{l}\text { Addition of Final } \\
\text { Phoneme }\end{array}$ & 24 & $11.21 \%$ & Mamsh/Mamshie \\
\hline Addition of Suffix & 12 & $5.61 \%$ & $\begin{array}{l}\text { Agreeness Boylet, } \\
\text { Feelingness, Isisisness, } \\
\text { Kalaness, Kumotness, } \\
\text { Pakeness, Tamaness, } \\
\text { Taoness, Nasightness, } \\
\text { Chikaness }\end{array}$ \\
\hline $\begin{array}{l}\text { Addition of Meaningless } \\
\text { Syllables }\end{array}$ & 12 & $5.61 \%$ & $\begin{array}{l}\text { Beslalu, Buysung, } \\
\text { Givesung, Gora, } \\
\text { Talamakers, Warla, } \\
\text { Jowabells/Jowa, Jowala, } \\
\text { Lafangers, Mudrakels }\end{array}$ \\
\hline $\begin{array}{l}\text { Addition of Medial } \\
\text { Phoneme }\end{array}$ & 3 & $1.40 \%$ & Beks \\
\hline $\begin{array}{l}\text { Addition of Initial } \\
\text { Phoneme }\end{array}$ & 3 & $1.40 \%$ & $\begin{array}{l}\text { Jikot, Jiwan/Jiniwan, } \\
\text { Jombag }\end{array}$ \\
\hline $\begin{array}{l}\text { Addition of Foreign } \\
\text { Words }\end{array}$ & 1 & $0.47 \%$ & Kalukaditang Kiyeme \\
\hline
\end{tabular}

Table 1 shows the linguistic deviation in swardspeak in terms of addition as spoken by the gay students. The different categories of addition with their respective exemplars were tabulated in terms of frequency and computed percentage. 
Addition of phonemes refers to the specific ability to enhance and manipulate the individual sounds (phonemes) in the spoken words. Phonemes are the smallest units comprising spoken language. Phonemes combine to form syllables and words. As shown in table 1, addition could occur into initial, final, and medial.

Based on the table 1, it revealed that addition of final phoneme has the highest percentage of $11.21 \%$ with frequency of 24 . This connotes that those gay students who used swardspeak mainly familiar with the common sound they heard regularly. The exemplar mamsh and mamshie were derived from the word mommy meaning mother. The changed in the final sound the word of origin was resulted as swardspeak use to address a female, whether young girls or older lady. In the part of addition of medial phoneme, it gained $1.4 \%$ with frequency of 3 using the swardspeak Beks. Addition of initial phoneme took place in swardspeak jikot, jiwan/jiniwan, jombag with $1.4 \%$ and frequency of 3 .

This result is supported by the findings of the study of Catacutan (2010) which revealed that swardspeak as a language regards hierarchies as a means to exploit gender. Although arguably, users of gayspeak do not have terms for ditse, sanse, diko, sangko, and bunso. The general term for a male is kuyey and for the female, atey (and its variants, e.g. teh, ateng, acheng). Bakla, baklush, badette can be used interchangeably between the two sexes, particularly for female acquaintances. "Language is an example of a control and conditioning factor in the overall thought of what gender is. Precedence of masculine over feminine words denotes dominance and superiority." In line with the addition of final phoneme with the term "mom" strongly showed the gender-based changes through addition of sounds. 
Based on the table 1, it also showed addition in terms of suffix, meaningless syllables, and foreign words. Adding of suffix to specific words can produce new words that express different meaning, like agreeness boylet, feelingness, isisisness, kalaness, kumotness, pakeness, tamaness, taoness, nasightness, chikaness; resulted to frequency of 12 with $5.61 \%$. Adding of meaningless syllables to words can produce new words that express different meaning, like beslalu, buysung, givesung, gora, talamakers, warla, jowabells/jowa, jowala, lafangers, mudrakels resulted to frequency of 12 with $5.61 \%$. Addition of foreign words to certain words can produce new words that express different meaning, like Kalukaditang Kiyeme resulted to frequency of 1 with $0.47 \%$.

This result is supported by the findings of the study of Sunguitan (2010) by using swardspeak, Filipino gays are able to resist the dominant culture of their area and create a space of their own. The language is constantly changing, with old phrases becoming obsolete and new phrases frequently entering everyday usage, reflecting changes in their culture and also maintaining exclusivity. The dynamic nature of the language refuses to cement itself in a single culture and allows for more freedom of expression among its speakers. Words and phrases can be created to react to the popular trends and create alternatives to a strictly defined lifestyle. By these characteristics, swardspeak creates a dissident group without any ties to geographical, linguistic, or cultural restrictions, thus allowing its speakers to shape the language as appropriate to the times. In this way, the languages are not only "mobile" and part of a larger community, but also open to more specific or local meanings.

Table 2 on the succeeding page shows linguistic deviation in swardspeak in terms of different categories of change as spoken by gay students. 
Table 2. Linguistic Deviation in Swardspeak as to Change as Spoken by Gay Students

\begin{tabular}{|l|c|c|l|}
\hline \multicolumn{1}{|c|}{ Category } & Frequency & Percentage & \multicolumn{1}{c|}{ Exemplar } \\
\hline Change of Final Phoneme & 27 & $12.62 \%$ & $\begin{array}{l}\text { Akes, Aketch, Anek, } \\
\text { Anes, Baklush, Ditey, } \\
\text { Ganern, Itech, Ites, Itey, } \\
\text { Ditey, Kakalurkey, } \\
\text { Ganders }\end{array}$ \\
\hline $\begin{array}{l}\text { Change of Initial } \\
\text { Phoneme }\end{array}$ & 19 & $8.88 \%$ & $\begin{array}{l}\text { Jasketball, Jinawa, } \\
\text { Jinujunit, Jinuyusan, } \\
\text { Jinyerahan, Jujutok, Julat } \\
\text { na julat, Jumonta, } \\
\text { Jumontok, Kabog, } \\
\text { Napakajonggoloid, } \\
\text { Pajonta, Pinagjulat, } \\
\text { Vaklang, Wait Anez, } \\
\text { Waley }\end{array}$ \\
\hline $\begin{array}{l}\text { Change of Medial } \\
\text { Phoneme }\end{array}$ & & & \\
\hline Complete Change & 10 & $4.67 \%$ & $\begin{array}{l}\text { Gurl/Ghorl, Kavaklaang, } \\
\text { Kakalurkey, Sisteret/Sis }\end{array}$ \\
\hline
\end{tabular}

Different categories of change with their respective exemplars were tabulated in terms of frequency and computed percentage.

Change of final phoneme gained the highest percentage of $12.62 \%$ and used by the students 27 times. Evident with the exemplar used like akes, aketch, anek, anes, baklush, ditey, ganern, itech, ites, itey, ditey, kakalurkey, ganders from each root words, changing the final phoneme expresses the artistic form in this deviation resulted to new definition. Same with the change of initial phoneme, jasketball, jinawa, jinujunit, jinuyusan, jinyerahan, jujutok, julat na julat, jumonta, jumontok, kabog, napakajonggoloid, pajonta, pinagjulat, vaklang, wait anez, and waley with $8.88 \%$ and frequency of 19. Change of medial phoneme resulted with frequency of 10 equivalent to $4.67 \%$ using swardspeak like gurl/ghorl, kavaklaang, kakalurkey, and sisteret/sis. Complete change exemplar anda was used 6 times with $2.80 \%$. 
Meanwhile, the result of linguistic deviation in swardspeak in terms of different categories of change as spoken by gay students demonstrated their higher creativity skills in using the language. Forming new words with unique concept widen their vocabularies and made it useful. The exclusive use of swardspeak marked as their identity within the school community.

The result is supported by Salao (2010); defining trait of swardspeak slang is that it more often than not immediately identifies the speaker as homosexual, making it easy for people of that orientation to recognize each other. This creates an exclusive group among its speakers and helps them resist cultural assimilation. More recently, though, even non-members of gay community use this way of speaking, particularly heterosexual members of industries dominated by gays, such as the fashion and film industries.

Table 3 on the next page shows linguistic deviation in swardspeak in terms of creation as spoken by gay students. Different categories of change with their respective exemplars were tabulated in terms of frequency and computed percentage.

Linguistic deviation in swardspeak in terms of creation under the category of Invention gained the highest frequency of 36 equivalents to $16.82 \%$. Exemplar used in the said category were baler, bongga, chaka, chararat, chika, here anda there, krungkrung, lafang, matigok, nota, otoko, pakiyeme, plangak, wit, wiz, jowabells/jowa, jowala, lafangers, mudrakels, and chikaness.

In terms of eponymy which resulted to 13 frequency and $6.07 \%$ with exemplar like Bilis Crawford, Farra Faucet, Hagardo Versosa, Jano Gibs, Luz Valdez, Nagpapajulie Yap Daza, OA Delas Alas, Rica Peralejo, Sa Catriona, Stress Drilon ranked second to the highest. 
Table 3. Linguistic Deviation in Swardspeak as to Creation as Spoken by Gay Students

\begin{tabular}{|c|c|c|c|}
\hline Category & Frequency & Percentage & Exemplar \\
\hline Invention & 36 & $16.82 \%$ & $\begin{array}{l}\text { Baler, Bongga, Chaka, } \\
\text { Chararat, Chika, Here } \\
\text { anda there, Krung-krung, } \\
\text { Lafang, Matigok, Nota, } \\
\text { Otoko, Pakiyeme, } \\
\text { Plangak, Wit, Wiz, } \\
\text { Jowabells/Jowa, Jowala, } \\
\text { Lafangers, Mudrakels, } \\
\text { Chikaness }\end{array}$ \\
\hline Eponymy & 13 & $6.07 \%$ & $\begin{array}{l}\text { Bilis Crawford, Farra } \\
\text { Faucet, Hagardo Versosa, } \\
\text { Jano Gibs, Luz Valdez, } \\
\text { Nagpapajulie Yap Daza, } \\
\text { OA Delas Alas, Rica } \\
\text { Peralejo, Sa Catriona, } \\
\text { Stress Drilon }\end{array}$ \\
\hline Clipping & 9 & $4.21 \%$ & $\begin{array}{l}\text { Baks, Boyfie, Kadirty, } \\
\text { Peeps, The, Sisteret/Sis, } \\
\text { Ganders }\end{array}$ \\
\hline Code Switching & 3 & $1.40 \%$ & $\begin{array}{l}\text { Nahear, Pagforce, } \\
\text { Nasightness }\end{array}$ \\
\hline Blending & 1 & $0.47 \%$ & Antaray \\
\hline Onomatopoeia & 1 & $0.47 \%$ & Ching chong \\
\hline
\end{tabular}

Clipping gained frequency of 9 with $4.21 \%$ used these exemplar baks, boyfie, kadirty, peeps, the, sisteret/sis, ganders. The categories blending and onomatopeia both resulted to frequency of 1 and $0.47 \%$ using these exemplar antaray and ching chong.

Based on the table, it was a result of the defining trait of swardspeak slang that it is more often than not immediately identifies the speaker as homosexual, making it easy for people of that orientation to recognize each other. This creates an exclusive group among gay students help them resist cultural assimilation. More recently, even nonmembers of the gay community have been known to use this way of speaking, outside or inside the school premises. The process of creation was derived from various famous 
personalities formed unique words. Nouns mainly name of artist were converted to different manner.

Likewise, quite on the rise recently is the usage of words in many different media - in film, radio, television, and even in print. Mass media, more particularly television, has been pivotal in the proliferation and dissemination of the words currently being used. The range of terminologies churned out by swardspeakers has become massive and extensive that almost all words can have equivalents or derivatives. Remoto (2010) qualifies this as swardspeak is "continuously updated." This, directly negates Garcia's mention of the limited scope of vocabulary swardspeak had, which was, unfortunately more focused on the physical and sexual overtones (Catacutan, 2012).

Table 4. Linguistic Deviation in Swardspeak as to Misanalysis as Spoken by Gay Students

\begin{tabular}{|l|c|c|l|}
\hline \multicolumn{1}{|c|}{ Category } & Frequency & Percentage & \multicolumn{1}{c|}{ Exemplar } \\
\hline $\begin{array}{l}\text { Phonemic } \\
\text { Association to call } \\
\text { out Existing Word }\end{array}$ & 13 & $6.07 \%$ & $\begin{array}{l}\text { Antibiotic (concept = against), } \\
\text { Channel (brand = fashion line), } \\
\text { Crayola, Deadmathology, Earth } \\
\text { ko (concept = world), Elsa ka } \\
\text { (movie character = beautiful), } \\
\text { Givenchy, Ice ice baby (song } \\
\text { someone special), Inlababo, } \\
\text { Nadedo, Pranelang } \\
\text { pranela (concept = paranoid), } \\
\text { Puritang purita }\end{array}$ \\
\hline $\begin{array}{l}\text { Recontextualization } \\
\text { of word }\end{array}$ & 11 & $5.14 \%$ & $\begin{array}{l}\text { Bet, Kembot, Keri, Knows } \\
\text { Repetition of } \\
\text { Misanalyzed Form }\end{array}$ \\
\hline 10 & $4.67 \%$ & $\begin{array}{l}\text { Care na care, Cold cold, } \\
\text { Dinodoing, Fight fight fight, Fly } \\
\text { fly, Pak na pak, Super duper, Sing } \\
\text { song, Anyare }\end{array}$ \\
\hline
\end{tabular}

Table 4 shows linguistic deviation in swardspeak in terms of misanalysis as Spoken by gay students. Different categories of change with their respective exemplars were tabulated in terms of frequency and computed percentage. 
Based on the table, phonemic association to call out existing word resulted as the highest category in terms of misanalysis. It gained frequency of 13 and $6.07 \%$ using these exemplar, antibiotic (concept = against), chanel (brand $=$ fashion line), crayola, deadmathology, Earth ko (concept = world), Elsa ka (movie character = beautiful), givenchy, ice ice baby (song = someone special), inlababo, nadedo, pranelang pranela (concept $=$ paranoid), and puritang purita (concept = very poor). The recontextualization of word resulted with frequency of 11 and 5.14\% from bet, kembot, keri, and knows. Repetition of misanalyzed form gained frequency of 10 and $4.67 \%$ from care na care, cold cold, dinodoing, fight fight fight, fly fly, pak na pak, super-duper, sing song, and anyare.

In like manner, the misanalysis on the given categories was results of bridge between the incredible diversity of the languages gay students formed. Acquiring such knowledge in swardspeak, abundance of misconception may occur from the speaker and the listener.

This result is supported by Salao (2010) that swardspeak uses elements from Tagalog, English, Spanish, and some from Japanese, as well as celebrities' names and trademark brands, giving them new meanings in different contexts. It is largely localized within gay communities, making use of the words derived from the local languages or dialects, including Cebuano, Hiligaynon, Waray, and Bicolano.

\section{Implications of the Use of Swardspeak to the Students' Language Competencies}

Table 5 on the succeeding page shows the implications on the use of swardspeak as identity marker among the gay students. The responses of each informant from the questions "Why do you use gay lingo? and What is the purpose of using the language?" were tabulated. From the responses of gay students, the significant codes were identified. 
Table 5. Implications on the Use of Swardspeak as Identity Marker among Gay Students

\begin{tabular}{|c|c|c|}
\hline Informant ID & Response & Code \\
\hline IN1 & $\begin{array}{l}\text { For me, the purpose of using gay lingo is } \\
\text { that it serves as our identity, it helps is be } \\
\text { distinct with other people and through this } \\
\text { we could identify ourselves and our kind. }\end{array}$ & Serves as identity \\
\hline IN2 & $\begin{array}{l}\text { I use gay lingo because I believe that is the } \\
\text { way to proof myself that I'm belong in that } \\
\text { community. }\end{array}$ & $\begin{array}{l}\text { Proof that they belong } \\
\text { in that community. }\end{array}$ \\
\hline IN6 & $\begin{array}{l}\text { I use gay lingo to express my social and } \\
\text { personal relations, to represent an } \\
\text { experience, and to show my identity. } \\
\text { The purpose of using this language is to } \\
\text { make it easy for people of that orientation to } \\
\text { recognize each other, we love to use } \\
\text { colorful words to hide real meanings, and } \\
\text { making people laugh out loud. }\end{array}$ & $\begin{array}{l}\text { To represent an } \\
\text { experience, to show } \\
\text { my identity and to } \\
\text { make it easy for } \\
\text { people of that } \\
\text { orientation to } \\
\text { recognize each other. }\end{array}$ \\
\hline IN7 & $\begin{array}{l}\text { The purpose of this language is to convince } \\
\text { everyone that using Gay Language is not } \\
\text { something to be ashamed of. It is a part of } \\
\text { community and we hear this language } \\
\text { everywhere that even women use it. By } \\
\text { using it, we can express our true selves. } \\
\text { Well for me, it is advantageous. }\end{array}$ & $\begin{array}{l}\text { To convince everyone } \\
\text { that using Gay } \\
\text { Language is not } \\
\text { something to be } \\
\text { ashamed of. }\end{array}$ \\
\hline IN8 & $\begin{array}{l}\text { Technically speaking, it doesn't have a very } \\
\text { definitive purpose. It is just there to show } \\
\text { what a distinct character a person has; } \\
\text { furthermore it was created so members of } \\
\text { the LGBTQ+ community can speak with } \\
\text { each other as means of identity. }\end{array}$ & $\begin{array}{l}\text { Show what a distinct } \\
\text { character a person has. }\end{array}$ \\
\hline \multirow[t]{2}{*}{ IN9 } & $\begin{array}{l}\text { Also that this particular language does not } \\
\text { have boundaries or set of rules with regards } \\
\text { the usage of such, we can use it freely. And } \\
\text { most importantly, we can showcase the } \\
\text { richness in creativity of our community, in } \\
\text { such way that we can truly uncover our } \\
\text { genuine identity. }\end{array}$ & $\begin{array}{l}\text { Showcase the richness } \\
\text { in creativity of our } \\
\text { community, in such } \\
\text { way that we can truly } \\
\text { uncover our genuine } \\
\text { identity. }\end{array}$ \\
\hline & $\begin{array}{l}\text { This aims to develop an affinity between } \\
\text { persons. And promotes equality despite our } \\
\text { individual differences that everyone can live } \\
\text { in their own choices and preferences. }\end{array}$ & $\begin{array}{l}\text { Individual differences } \\
\text { everyone can live in } \\
\text { their own choices and } \\
\text { preferences. }\end{array}$ \\
\hline IN11 & $\begin{array}{l}\text { I use gay lingo as language for easily } \\
\text { understand and communicate with my } \\
\text { fellow gay because we have the same }\end{array}$ & $\begin{array}{l}\text { Use it for fun and as } \\
\text { metaphor in } \\
\text { addressing it. }\end{array}$ \\
\hline
\end{tabular}


gender preference. Sometimes we use it for

fun and as metaphor in addressing it to

other.

Based on the table, Informant 1 stated "For me, the purpose of using gay lingo is that it serves as our identity, it helps us be distinct with other people and through this we could identify ourselves and our kind." resulted with the code Serves as identity (IN1). Informant 2 specified "I use gay lingo because I believe that is the way to proof myself that I'm belong in that community." resulted with the code Proof that they belong in that community (IN2).

Informant 6 stated "I use gay lingo to express my social and personal relations, to represent an experience, and to show my identity. The purpose of using this language is to make it easy for people of that orientation to recognize each other, we love to use colourful words to hide real meanings, and making people laugh out loud." Resulted with the code to represent an experience, to show my identity and to make it easy for people of that orientation to recognize each other (IN6).

Informant 7 specified "The purpose of this language is to convince everyone that using gay language is not something to be ashamed of. It is a part of community and we hear this language everywhere that even women use it. By using it, we can express our true selves. Well for me, it is advantageous." resulted with the code to convince everyone that using gay language is not something to be ashamed of (IN7).

Informant 8 stated 'technically speaking, it doesn't have a very definitive purpose. It is just there to show what a distinct character a person has; furthermore it was created so members of the LGBTQ+ community can speak with each other as means of identity." resulted with the code Show what a distinct character a person has (IN8). 
Informant 9 shared "also that this particular language does not have boundaries or set of rules with regards the usage of such, we can use it freely. And most importantly, we can showcase the richness in creativity of our community, in such way that we can truly uncover our genuine identity. This aims to develop an affinity between persons. And promotes equality despite our individual differences that everyone can live in their own choices and preferences." resulted with the code Showcase the richness in creativity of our community, in such way that we can truly uncover our genuine identity as well as individual differences everyone can live in their own choices and preferences (IN9).

Informant 11 stated "I use gay lingo as language for easily understand and communicate with my fellow gay because we have same gender preference. Sometimes we use it for fun and as metaphor in addressing it to other." resulted with the code Use it for fun and as metaphor in addressing it (IN11).

Gay students were often raised in communities that are either ignorant of or openly hostile toward homosexuality. Because sexual identity development is a process for which gay individuals have been unprepared and which is contextually unsupported and stigmatized, it would seem that the process would be characterized by inconsistency or incongruence among its affective, cognitive, and behavioural components, such that behaviour may not always coincide with affect and identity. Evident with the results, majority of the responses dealt with the eagerness of gay students to specify their identity within the community. Gay students wanted to gained respect by showing bluntly their remarked identity.

Among the responses of each informant youth expressed strong values in regards to respecting people's identities within the community and outside as well. Gay Students' 
community feels it is important not to assume a person's identity or gender based on their physical appearance or gender expression.

This result is supported by the findings of the study conducted by Castro (2013) in Introduction: Gender, language and translation at the crossroads of disciplines, "language is a political act of mediation and communication which either perpetuates or challenges existing power structures within wider social and cultural contexts." The birth of a common language among gays clearly and explicitly defies the culture that the Philippines have had. It tried to break away from the dualistic perspective of life - heaven and hell, black and white, man and woman. Swardspeak was the weapon that Filipino gay men used to connect with other gays - those who are discriminated, oppressed, and ridiculed and belittled.

Table 6 shows the implications on the use of swardspeak as Self-expression among gay students. The responses of each informant from the questions "Why do you use gay lingo?and What is the purpose of using the language?" were tabulated. From the responses of the gay students, the researcher identified the significant point as code.

Based on the table, Informant 3 specified "In short, it is our way to freely express ourselves, because we all knew the fact that other people are close-minded and sensitive, so they might get offended if we talk straight or bluntly the language so to avoid such incidents we used gay lingo" resulted with the code way to freely express theirselves (IN3). Informant 4 mentioned "I use gay lingo to express myself more as an individual considering that I am a homosexual" resulted with the code express their selves (IN4). Informant 5 stated "I must say, as a gay I use gay lingo to make the tone of the sentence as light, and enjoyable as possible, since the basis of the vocabulary are mostly made up with imagination for fun which made to bridge one another as a mean of communication" 
Table 6. Implications on the Use of Swardspeak as Self-expression among Gay Students

\begin{tabular}{|c|c|c|}
\hline Informant ID & Response & Code \\
\hline IN3 & $\begin{array}{l}\text { In short, it is our way to freely express } \\
\text { ourselves, because we all knew the fact that } \\
\text { other people are close-minded and sensitive, } \\
\text { so they might get offended if we talk straight } \\
\text { or bluntly the language so to avoid such } \\
\text { incidents we used Gay Lingo. }\end{array}$ & $\begin{array}{l}\text { Way to freely } \\
\text { express themselves. }\end{array}$ \\
\hline IN4 & $\begin{array}{l}\text { I use gay lingo to express myself more as an } \\
\text { individual considering that I am a } \\
\text { homosexual. }\end{array}$ & Express their selves \\
\hline IN5 & $\begin{array}{l}\text { I must say, as a gay I use gay lingo to make } \\
\text { the tone of the sentence as light, and } \\
\text { enjoyable as possible, since the basis of the } \\
\text { vocabulary are mostly made up with } \\
\text { imagination for fun that has made to bridge } \\
\text { one another as a mean of communication. }\end{array}$ & $\begin{array}{l}\text { To make the tone } \\
\text { of the sentence as } \\
\text { light, and enjoyable } \\
\text { as possible }\end{array}$ \\
\hline IN7 & $\begin{array}{l}\text { It is a part of community and we hear this } \\
\text { language everywhere that even women use it. } \\
\text { By using it, we can express our true selves. } \\
\text { Well for me, it is advantageous. }\end{array}$ & $\begin{array}{l}\text { By using it, they } \\
\text { can express our } \\
\text { true selves }\end{array}$ \\
\hline IN10 & $\begin{array}{l}\text { I used this gay language because it defines me } \\
\text { as who I am. It is merely accepted both gays } \\
\text { and non gays as an expression as well, it } \\
\text { serves as an armor to shield ourselves from } \\
\text { chasm and social stigma caused by gender } \\
\text { differences }\end{array}$ & $\begin{array}{l}\text { Merely accepted } \\
\text { both gays and non- } \\
\text { gays as an } \\
\text { expression as well. }\end{array}$ \\
\hline IN9 & $\begin{array}{l}\text { Also that this particular language does not } \\
\text { have boundaries or set of rules with regards } \\
\text { the usage of such, we can use it freely. }\end{array}$ & $\begin{array}{l}\text { No boundaries or } \\
\text { set of rules with } \\
\text { regards the usage } \\
\text { of such, we can use } \\
\text { it freely }\end{array}$ \\
\hline
\end{tabular}

resulted with the code to make the tone of the sentence as light, and enjoyable as possible (IN5). Informant 7 specified "It is a part of community and we hear this language everywhere that even women use it. By using it, we can express our true selves. Well for me, it is advantageous." resulted with the code By using it, they can express our true selves (IN7). Informant 4 stated "I used this gay language because it defines me as who I am. It is merely accepted both gays and non-gays as an expression as well, it serves as an 
armor to shield ourselves from chasm and social stigma caused by gender differences." resulted with code merely accepted both gays and non-gays as expression as well (IN10). Informant 9 specified "that this particular language does not have boundaries or set of rules with regards the usage of such, we can use itfreely." resulted with the code No boundaries or set of rules with regards the usage of such, we can use it freely (IN9).

Based on the responses of the informants, it is evident that own unique quirks and traits, and own preferences and style for sharing pieces of their identity was shown thru swardspeak. How they shared and expressed to others formed basis of their personality, and sets the tone for entire atmosphere. Swardspeak is a vital aspect of their life to pay attention to, especially gay students wanted to feel more understood and more in tune with the people you they cared about.

This result is supported by the findings of the study conducted by Racoma (2013) swardspeak has been using this mode to express their ideas. From the time that freedom of expression has regained its footing in the Philippines after the 1986 revolution, a lot has already been founded. From the 80 s to the early years of 2000s, two shows have been created by Philippine television network GMA-7 which catered to gay speak - Giovanni Calvo's Katok mga Misis and Out - both of which had segments that dedicated to explaining the meanings and etymologies of gay terms. These shows have made the swardspeak experience transcend into national awareness by means of mass media. In the more recent years, Vice Ganda of Showtime was able to concoct terms that have gained national scope and usage with anyare and ansaveh, to name a few.

Table 7 shows the implications on the use of swardspeak as Concealment among gay students. The responses of each informant from the questions "Why do you use gay lingo? and What is the purpose of using the language?" were tabulated. 
Table 7. Implications on the Use of Swardspeak as Concealment among Gay Students

\begin{tabular}{|l|l|l|}
\hline Informant ID & \multicolumn{1}{|c|}{ Response } & \multicolumn{1}{|c|}{ Code } \\
\hline IN4 & $\begin{array}{l}\text { There are some words that we think are } \\
\text { "understatements" to what we think its true } \\
\text { meaning are. I think it is best to use gay lingo } \\
\text { to hide some conversation to other people } \\
\text { who do not use it. }\end{array}$ & $\begin{array}{l}\text { To hide some } \\
\text { conversation. }\end{array}$ \\
\hline IN2 & $\begin{array}{l}\text { I use gay lingo because I believe that is the } \\
\text { way to proof myself that I'm belong in that } \\
\text { community. }\end{array}$ & $\begin{array}{l}\text { Proof that they } \\
\text { belong in that } \\
\text { community. }\end{array}$ \\
\hline IN6 & $\begin{array}{l}\text { The purpose of using this language is to make } \\
\text { it easy for people of that orientation to } \\
\text { recognize each other, we love to use colorful } \\
\text { words to hide real meanings, and making } \\
\text { people laugh out loud. }\end{array}$ & $\begin{array}{l}\text { Love to use colorful } \\
\text { words to hide real } \\
\text { meanings, and } \\
\text { making people } \\
\text { laugh out loud. }\end{array}$ \\
\hline IN12 & $\begin{array}{l}\text { lide the explicit content of our conversation } \\
\text { to others who don't understand our language. }\end{array}$ & $\begin{array}{l}\text { To hide the explicit } \\
\text { content of our } \\
\text { conversation. }\end{array}$ \\
\hline
\end{tabular}

From the responses of the gay students, the researcher identified the significant point as code. Based on the table, Informant 4 specified "There are some words that we think are "understatements" to what we think its true meaning are. I think it is best to use gay lingo to hide some conversation to other people who do not use it" resulted with the code To hide some conversation (IN4).

Informant 2 specified "I use gay lingo because I believe that is the way to proof myself that I'm belong in that community." resulted with the code Proof that they belong in that community (IN2). Informant 6 stated "The purpose of using this language is to make it easy for people of that orientation to recognize each other, we love to use colorful words to hide real meanings, and making people laugh out loud." resulted with the code Love to use colorful words to hide real meanings, and making people laugh out loud (IN6). Informant 12 specified "I usually use gay lingo in communication to hide the explicit content of our conversation to others who don't understand our language." resulted with the code To hide the explicit content of our conversation (IN12). 
Based on the responses of each informant under the classification of concealment, it is evident that using swardspeak was a major tool gay students' used to hide the explicit content of their conversation. Swardspeak as disguised with the real content of their conversations helped them have privacy.

This result is supported by the findings of the study conducted by Hayes (2016) swarspeak is characterized by an abundance of sex themed expressions and expressions for physical appearance, as well as intimacy of relationship, rank and eccentricities within the subculture. It was important for gays to keep the language hidden from the majority which resulted in "over-lexicalization of terms for sex, body parts, and people" (Taylor, 2017) and are direct reflections of abstract thoughts based on literal ones. Today, with gays being more and more accepted in society, the domains of interest or, in this case, lexical domains are easier to understand and because of that it is possible to conduct a metaphorical conceptualization.

Table 8 on the succeeding page shows the implications on the use of swardspeak as Softener among gay students. The responses of each informant from the questions "Why do you use gay lingo?and What is the purpose of using the language?" were tabulated. From the responses of the gay students, the researcher identified the significant point as code.

Based on the table, Informant 4 specified "There are some words that we think are "understatements" to what we think its true meaning are. I think it is best to use gay lingoto hide some conversation to other people who do not use it." resulted with the code Understatements (IN4). Informant 5 specified "I think the purpose of using this language is that to respect by other people when gays are having a conversation especially when it 
Table 8. Implications on the Use of Swardspeak as Softener among Gay Students

\begin{tabular}{|c|c|c|}
\hline Informant ID & Response & Code \\
\hline IN4 & $\begin{array}{l}\text { There are some words that we think are } \\
\text { "understatements" to what we think its true } \\
\text { meaning are. I think it is best to use gay lingo to } \\
\text { hide some conversation to other people who do } \\
\text { not use it. }\end{array}$ & Understatements \\
\hline IN5 & $\begin{array}{l}\text { I think the purpose of using this language is that } \\
\text { to respect by other people when gays are having } \\
\text { a conversation specially when it comes to the } \\
\text { person with "virgin ears" and also as I observe } \\
\text { the purpose of using "gay lingo" in social media } \\
\text { it serves as a disguise to their own opinions } \\
\text { especially during this crisis held by the terror bill } \\
\text { passed by the government. }\end{array}$ & $\begin{array}{l}\text { To respect by } \\
\text { other people } \\
\text { when gays are } \\
\text { having a } \\
\text { conversation }\end{array}$ \\
\hline
\end{tabular}

comes to the person with "virgin ears" and also as I observe the purpose of using "gay lingo" in social media it serves as a disguise to their own opinions especially during this crisis held by the terror bill passed by the government." resulted with the code To respect by other people when gays are having a conversation (IN5).

Evident with the responses of gay students, swardspeak was used as language softeners were relevant to their sense of belongingness. When external conditioning makes its usage more mandated and significant for one gender over another, they felt accepted by the community.

This result is supported from the literary writings of Taylor (2017) since gays were marginalized more than today, at least in the developed countries, it was crucial for them to create a language which an outsider will not know about. "Secret languages emerge from situations in which a community feels the need to conceal the content of their utterances from the outside world" and that community is "threatened by other communities" (Taylor, 2017). The language ancestor of modern gayspeak is Polari, the underground language, or to be exact, a jargon and a secret vocabulary used not only by 
homosexuals, but also showmen, criminals, gypsies, men serving in the navy, etc. Since homosexuals were, and still are, but with more equal rights than ever in history, insecure about their lives, especially during the World War II and afterwards, they felt the need to speak in a manner of the "overall structure of a larger language, with a coded lexicon" to feel more-or-less equal to everyone else, to pass vital information incognito, and, to start to feel more human ultimately.

Table 9. Implications on the Use of Swardspeak as Emancipation among Gay Students

\begin{tabular}{|c|c|c|}
\hline Informant ID & Response & Code \\
\hline IN7 & $\begin{array}{l}\text { The purpose of this language is to } \\
\text { convinceeveryone that using Gay Language is } \\
\text { not something to be ashamed of. It is a part of } \\
\text { community and we hear this language } \\
\text { everywhere that even women use it. }\end{array}$ & $\begin{array}{l}\text { To convince } \\
\text { everyone that using } \\
\text { Gay Language is } \\
\text { not something to be } \\
\text { ashamed of. }\end{array}$ \\
\hline IN9 & $\begin{array}{l}\text { It's just something that forms bonds or } \\
\text { connections with my fellow LGBTQ members. } \\
\text { It destroys the barrier that separates the } \\
\text { community to the society and liberates the } \\
\text { society from the dominance of hatred to foster } \\
\text { respect and acceptance with the community. }\end{array}$ & $\begin{array}{l}\text { Forms bonds or } \\
\text { connections with } \\
\text { my fellow LGBTQ } \\
\text { members. } \\
\text { Destroys the } \\
\text { barrier. }\end{array}$ \\
\hline $\mathrm{IN} 10$ & $\begin{array}{l}\text { I used this gay language because it defines me } \\
\text { as who I am. It is merely accepted both gays } \\
\text { and non-gays as an expression as well, it } \\
\text { serves as an armor to shield ourselves from } \\
\text { chasm and social stigma caused by gender } \\
\text { differences. I used this way of speaking to } \\
\text { recognize each other. }\end{array}$ & $\begin{array}{l}\text { Serves as an armor } \\
\text { to shield ourselves } \\
\text { from chasm and } \\
\text { social stigma. }\end{array}$ \\
\hline
\end{tabular}

Table 9 shows the implications on the use of swardspeak as Emancipation among gay students. The responses of each informant from the questions "Why do you use gay lingo?and What is the purpose of using the language?" were tabulated. From responses of the gay students, the researcher identified the significant point as code. Based on the table, Informant 7 specified "The purpose of this language is to convince everyone that using Gay Language is not something to be ashamed of. It is a part of community and we hear 
this language everywhere that even women use it." resulted with the code To convince everyone that using Gay Language is not something to be ashamed of (IN7).

Informant 9 stated 'It's just something that forms bonds or connections with my fellow LGBTQ members. It destroys the barrier that separates the community to the society and liberates the society from the dominance of hatred to foster respect and acceptance with the community." resulted with the codes Forms bonds or connections with my fellow LGBTQ members and Destroys the barrier (IN9).

Informant 10 specified "I used this gay language because it defines me as who I am. It is merely accepted both gays and non-gays as an expression as well, it serves as an armor to shield ourselves from chasm and social stigma caused by gender differences. I used this way of speaking to recognize each other." resulted with the code Serves as an armor to shield ourselves from chasm and social stigma (IN10).

Evident with the responses of gay students their eagerness to free their selves with the controlling power of being judged by the society. Swardspeak served as weapon that shielded them with disrespects of people. Barriers were destroyed and bridges were building thru the use of swardspeak.

This result is supported by the findings of the study conducted by Alba (2016) swardspeak is the language of Filipino gay men. However, with its current user base, it is not exclusive to the mentioned population. Even women these days are known to have been using swardspeak. The use of swardspeak has become prevalent even among women; those who are referred to as babaeng bakla (Garcia, 2015), also known as fag hag, as early as four decades ago. Aside from this, swardspeak is also adaptive. A set of gay vocabulary is determined by the social class the user belongs to, since many if not all of the words created or modified in swardspeak is from another language. 


\section{Chapter V}

\section{SUMMARY OF FINDINGS, CONCLUSIONS, AND RECOMMENDATIONS}

This chapter discusses the summary of findings, the conclusions drawn from the results, and the recommendations offered thereafter.

\section{Summary}

This study aimed to reveal the implications of linguistic deviations of swardspeak to the language competencies of the gay students. In particular, this study also aimed to determine the linguistic deviations in swardspeak used by the gay students; investigate the implications of the use of swardspeak to the language competencies of the students; and develop a sociolinguistic primer on swardspeak and its linguistic deviations.

Using qualitative method of research, the researcher subjected 12 informants from Suba National High School in a recorder raw conversation using swardspeak. They were officially enrolled as high school students for the school year 2019 to 2020 . Recording protocol were drafted to gather the needed data which were transcribed, coded, and categorized to set the group of linguistic deviations which represented and generalized the experiences of the informants.

\section{Findings}

Based on the research problems, the following findings are unveiled:

1. Based on the result of tabulated and categorized set of linguistic deviations made by the informants, revealed the significant process of using swardspeak. Choosing not to follow the norms of language made them use it creatively with specific purpose. 
From the category of linguistic deviation in terms of addition showed the importance of single unit of sound. The relevance of adding in initial, final, medial phoneme, suffix and foreign words created a unique word forms. Swardspeak in this manner is an example of control and conditioning factor in overall thought of what gender is.

Meanwhile, linguistic deviations in terms of the change made from initial, medial, final of phoneme and complete change shows the same relevance of forming new unique concept widens their vocabularies and made it useful.

Linguistic deviation in terms of creation marked the formed of new concept of the swardspeak. Under this category were invention, eponymy, clipping, code switching, blending, and onomatopoeia. The defining trait of swardspeak slang that it is more often than not immediately identifies the speaker as homosexual, making it easy for people of that orientation to recognize each other. This creates an exclusive group among gay students help them resist cultural assimilation.

Under the category of misanalysis were results of bridge between incredible diversity of languages gay students formed. Acquiring knowledge in swardspeak occurred in terms of repetition of misanalyzed form, recontextualization of word, and phonemic association to call out existing word.

2. Investigating the implications of the use of swardspeak to the language competencies of the students revealed the abundance of diversity. Implications on the use of swardspeak as identity marker that the youth expressed strong values in regards to respecting people's identities within a community and outside as well. Gay students' community feels it is important not to assume a person's identity or gender based on their physical appearance or gender expression. Implications on the use of swardspeak 
as self-expression evident that own unique quirks and traits, and own preferences and style for sharing pieces of their identity was shown thru swardspeak. How they shared and expressed to others formed the basis of their personality, and sets the tone for entire atmosphere. Implications on the use of swardspeak as concealment revealed that using swardspeak was a major tool gay students' used to hide the explicit content of their conversation. swardspeak as disguised with real content of their conversations helped them have privacy. Implications on the use of swardspeak as softener were relevant to their sense of belongingness. When external conditioning makes its usage more mandated and significant for one gender over another, they felt accepted by the community. Implications on the Use of Swardspeak as Emancipation Swardspeak served as weapon that shielded them with disrespects of people. Barriers were destroyed and bridges were building thru the use of swardspeak.

3. A sociolinguistic primer on swardspeak and its linguistic deviations was developed.

\section{Conclusions}

Based on the research results, the following conclusions are derived:

1. A linguistic deviation on the process of using swardspeak depends on the ability of the students. The significant role of creativity and linguistic capability may be develop and improve with frequent use of the language.

2. Implications on the use of swardspeak provide identity for gay students, develop their self-expression, deliver exclusive space through concealment, and find comfort zone using their language.

3. The proposed sociolinguistic primer on swardspeak and its linguistic deviations is ready for initial implementation and assessment. 


\section{Recommendations}

Based on the conclusions, the following recommendations are offered:

1. Every language students might be encourage in using the language creatively and apply it in the learning process.

2. Activities in terms of speaking can always practice in the language learning process to boost the confidence of the students in expressing their ideas.

3. Familiarization of the linguistic deviation categories must be discussed to support the students improve their linguistic ability.

4. Follow up study may be conducted with the use of swardspeak in a new phase, new sets of participants, and different language functions. 


\section{REFERENCES CITED}

Alba, R. (2006). "The Filipino Gayspeak (Filipino Gay Lingo)." National Commission for Culture and the Arts, June 05, 2006. Web. November 18, 2003.

Ayensu, E. (2003). Communication and Culture in Ghana: Technology's Influence and Progress in a New Digital Age. Retrieved 14 April 2016 from http://home.ubalt. edu/ub78145/MY\%20ibrary/storage5DTZ9QTP/ElaineAyensu.pdf

Baker, P. (2010). Will Ms ever be as frequent as Mr? a corpus-based comparison of gendered terms across four diachronic corpora of British English. Gender and Language, 4 (1); 125-129

Barrett, G. (2010). Retrieved from https://www.waywordradio.org/swardspeak/

Bobeda, T. (2012). What gay sounds like: The linguistics of the LGBTQ communities. WBEZ 91.5 Chicago. Chicago Public Media. 11 June 2012. Web. Accessed on 10 April 2014. http://www.wbez.org/series/front-center/what-gay-sounds-linguisticslgbtq-communities 99994

Casabal, N. (2008) "Gay Language: Defying the Structural Limits of English Language in the Philippines.” Kritika Kultura 11 (2008): 74-101. Web.November 18, 2003.

Catacutan, S. (2012). "Gender and Language". MMS111 - Gender and Multimedia. University of the Philippines Open University (2012): $2^{\text {nd }}$ semester. Web.

Crystal, D. (1992). The changing English language: Fiction and fact. In M. Pütz (ed). Thirty years of the linguistic evolution (pp.119-130) Amsterdam: Benjamins. Retrieved 22 April 2012 from http://www.davidcrystal.com/DC_articles/English 58.pdf

Elman, J. L. (2010). Language as a dynamic system. University of California, San Diego. Retrieved from https://crl.ucsd.edu/ elman/Papers/dynamics/dynamics.html.

Essays, UK. (November 2018). The relationship between language and gender. Retrieved from https://www.ukessays.com/essays/sociology/the-relationship-between-langu age-and-gender-sociology-essay.php?vref $=1$

Garcia, N. (2006). Philippine gay culture. Quezon City. University of the Philippines Press.

Gianan, E. (2008) “The Evolution and Expansion of Gay Language in the Philippines". Scribd.com, 2008.Web. November 18, 2003

https://www.britannica.com/topic/language David Crystal Robert and Henry Robins 2011 
https://www.academia.edu/10107763/analysis_of_the_spoken_discourse_using_hymes_s _ethnography_of_speaking_model analysis of the spoken discourse using hymes's ethnography of speaking model, Rozman

https://www.youtube.com/watch?v=DRF_Ruj6VYY

http://www.gender.cawater-info.net/what/index_e.htm. Gender in practice. Swiss agency for development and cooperation

https://www.edu.gov.mb.ca/k12/cur/languages/as1/framework/language_competence.pdf

http://dx.doi.org/10.15446/profile.v19n1.56209 A Learning Experience of the Gender Perspective in English Teaching Contexts Aprendizajes de la perspectiva de género en los escenarios para la enseñanza del inglés Claudia Patricia Mojica1* Universidad de Los Andes, Bogotá, Colombia Harold Castañeda-Peña** Universidad Distrital Francisco José de Caldas, Bogotá, Colombia

Journal of Humanities and Cultural Studies R\&D The University of British Columbia, Humanities, Faculty Member | Humanities+9 Journal of Humanities and Cultural Studies R\&D http://www.jsrd-humanities.comhttps://www.academia.edu /298122 30/How_Cultures_Talk_Study_of_Dell_Hymes_Ehnography_of_Communication

Mallinson, C. \& Kendall, T. (2013). "Interdisciplinary Approaches." Oxford Handbook of Sociolinguistics, ed. by Robert Bayley, Richard Cameron, and Ceil Lucas. Oxford University Press.

McDonald, R. (2011). Language gender reading list. Retrieved from https://www.nypl. org/blog/2011/03/15/language-gender-reading-list by Kingsbridge Library March 18, 2011 https://www.researchgate.net/publication /253291274_Gender_Differe nces_in_language_use_an_analysis_of_14000_Text_SamplesDiscourse Processes $45(3): 2 \overline{1} 1-236$.

Mhute, I. (2008). Language and Gender. Open Society Initiative for Southern Africa. Vol 2 (3). Retrieved on 30 August 2010 from http://www.osisa.org/resources/docs/PD Fs/OpenSpace-Nov2008/2_3_language_p060-063_isaac_mhute.pdf

Mustapha, A. S. (2013). Journal of Language Teaching and Research, Vol. 4, No. 3, pp.454-463, May 2013 (C) 2013 Academy Publisher Manufactured in Finland. Sheffield Hallam University, United Kingdom; Lagos State University, Nigeria

Nguyen, Van Han (2011). Global Journal of Interdisciplinary Social Sciences, The Relationship between the Language and Gender: A Case Study in Vietnamese College of Finance and Customs, B2/1A. 385 Street, Tang Nhon Phu A Ward, District 9, Ho Chi Minh City, Vietnam 
Paula, E. (2010). The Gender Revolution: Uneven and Stalled. Gender and Society. 2010 24:149. Retrieved 22 August 2010 from http://gas.sagepub.com/content/24/2/149.

Pennebaker, J. (May 2008). 5,664 Reads DOI: 10.1080/01638530802073712 University of Texas at Austin.

Plattner, L. \& Otaala, L., Laura, A. \& Ilse E. www.sciedu.ca/ijhe International Journal of Higher Education Vol. 2, No. 3; 2013 Published by Sciedu Press 123 ISSN 19276044 E-ISSN 1927-6052 Implicit Beliefs about English Language Competencies in the Context of Teaching and Learning in Higher Education: A Comparison of University Students and Lecturers in Namibia Department of Languages, Uganda Martyrs University, Kampala, Uganda 2 Department of Psychology, University of Botswana, Botswana

Remoto, D. (2003). “On Philippine gay lingo.” ABS-CBNnews.com, May 5, 2008. Web. November 18, 2003.

Shazu, Rafiul Islam (2014). Journal of Education and Practice www.iiste.org ISSN 22221735 (Paper) ISSN 2222-288X (Online) Vol.5, No.14, 2014, Student of M.A.

Sims, A. D. (2014). Gayspeak. glbtq: the world's largest encyclopedia of gay, lesbian, bisexual, transgender, and queer culture. glbtq, Inc. 2004. Web.Accessed on 10 April 2014.http://www.glbtq.com/social-sciences/gayspeak.html

Taylor, H. (2007). Polari: A sociohistorical study of the life and decline of a secret language. The University of Manchester.

Xia, Xiufang Qingdao (2013). Theory and Practice in Language Studies, Vol. 3, No. 8, pp. 1485-1489, August 2013. Academy Publisher Manufactured in Finland. doi: 10.4304/tpls.3.8.1485-1489 Gender Differences in Using Language University of Science and Technology, China 
APPENDICES 


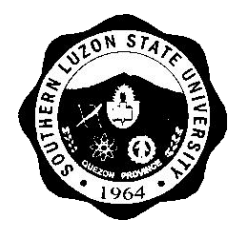

\title{
Appendix A \\ COMMUNICATIONS
}

\author{
Request Letter for the Conduct of the Study \\ Republic of the Philippines \\ Southern Luzon State University \\ COLLEGE OF TEACHER EDUCATION
}

March 5, 2020

Mr. ARCHIE M. CONDINO

Principal I, Suba National High School

Majayjay, Laguna

Dear Sir:

Greetings!

The undersigned is a graduate student of Southern Luzon State University and is presently conducting a study on LINGUISTIC DEVIATIONS OF SWARDSPEAK AND ITS IMPLICATION TO THE GAY STUDENTS' ENGLISH LANGUAGE COMPETENCIES for the completion of the requirements for the degree Master of Arts in Teaching English.

In connection with this, she is respectfully asking permission from your good office to conduct her study among selected gay high school students of Suba National High School. Likewise, she is also requesting permission to conduct an interview with the chosen participants for this study.

Your kind and favorable approval on this request will be of great help in the completion of her study. Attached to this letter is the copy of the guide question for the qualitative interview. Thank you very much. May God bless you always!

Very truly yours,

(SGD.) JOY ANN PURAL RUBIALES

Researcher

Noted:

(SGD.) LUIS MIGUEL P. SALUDEZ, Ph.D

Research Adviser 
Appendix B

\section{CATEGORIES OF RESPONSES}

Frequency of Swardspeak Used

\begin{tabular}{|c|c|c|c|c|}
\hline Category & Frequency & Exemplar & $\begin{array}{l}\text { Total per } \\
\text { Category }\end{array}$ & Percentage \\
\hline $\begin{array}{l}\text { Addition of Final } \\
\text { Phoneme }\end{array}$ & 24 & Mamsh/Mamshie & 24 & $11.21 \%$ \\
\hline $\begin{array}{l}\text { Addition of Foreign } \\
\text { Words }\end{array}$ & 1 & $\begin{array}{l}\text { Kalukaditang } \\
\text { Kiyeme }\end{array}$ & 1 & $0.47 \%$ \\
\hline \multirow[t]{3}{*}{$\begin{array}{l}\text { Addition of Initial } \\
\text { Phoneme }\end{array}$} & 1 & Jikot & 3 & $1.40 \%$ \\
\hline & 2 & Jiwan/Jiniwan & & \\
\hline & 2 & Jombag & & \\
\hline \multirow[t]{10}{*}{$\begin{array}{l}\text { Addition of Meaningless } \\
\text { Syllables }\end{array}$} & 1 & Beslalu & 12 & $5.61 \%$ \\
\hline & 1 & Buysung & & \\
\hline & 1 & Givesung & & \\
\hline & 1 & Gora & & \\
\hline & 1 & Talamakers & & \\
\hline & 1 & Warla & & \\
\hline & 3 & Jowabells/Jowa & & \\
\hline & 1 & Jowala & & \\
\hline & 1 & Lafangers & & \\
\hline & 1 & Mudrakels & & \\
\hline $\begin{array}{l}\text { Addition of Medial } \\
\text { Phoneme }\end{array}$ & 3 & Beks & 3 & $1.40 \%$ \\
\hline \multirow[t]{10}{*}{ Addition of Suffix } & 1 & Agreeness Boylet & 12 & $5.61 \%$ \\
\hline & 3 & Feelingness & & \\
\hline & 1 & Isisisness & & \\
\hline & 1 & Kalaness & & \\
\hline & 1 & Kumotness & & \\
\hline & 1 & Pakeness & & \\
\hline & 1 & Tamaness & & \\
\hline & 1 & Taoness & & \\
\hline & 1 & Nasightness & & \\
\hline & 1 & Chikaness & & \\
\hline Blending & 1 & Antaray & 1 & $0.47 \%$ \\
\hline \multirow[t]{3}{*}{ Change of Final Phoneme } & 4 & Akes & 27 & $12.62 \%$ \\
\hline & 4 & Aketch & & \\
\hline & 1 & Anek & & \\
\hline
\end{tabular}




\begin{tabular}{|c|c|c|c|c|}
\hline & 2 & Anes & & \\
\hline & 1 & Baklush & & \\
\hline & 2 & Ditey & & \\
\hline & 1 & Ganern & & \\
\hline & 3 & Itech & & \\
\hline & 6 & Ites & & \\
\hline & 1 & Itey & & \\
\hline & 2 & Ditey & & \\
\hline & 2 & Kakalurkey & & \\
\hline & 1 & Ganders & & \\
\hline \multirow{16}{*}{ Change of Initial Phoneme } & 1 & Jasketball & 19 & $8.88 \%$ \\
\hline & 1 & Jinawa & & \\
\hline & 1 & Jinujunit & & \\
\hline & 1 & Jinuyusan & & \\
\hline & 1 & Jinyerahan & & \\
\hline & 1 & Jujutok & & \\
\hline & 1 & Julat na julat & & \\
\hline & 1 & Jumonta & & \\
\hline & 1 & Jumontok & & \\
\hline & 4 & Kabog & & \\
\hline & 1 & Napakajonggoloid & & \\
\hline & 1 & Pajonta & & \\
\hline & 1 & \begin{tabular}{|l} 
Pinagjulat \\
\end{tabular} & & \\
\hline & 1 & Vaklang & & \\
\hline & 1 & Wait Anez & & \\
\hline & 1 & Waley & & \\
\hline \multirow[t]{4}{*}{$\begin{array}{l}\text { Change of Medial } \\
\text { Phoneme }\end{array}$} & 6 & Gurl/Ghorl & 10 & $4.67 \%$ \\
\hline & 1 & Kavaklaang & & \\
\hline & 2 & Kakalurkey & & \\
\hline & 1 & Sisteret/Sis & & \\
\hline \multirow[t]{7}{*}{ Clipping } & 3 & Baks & 9 & $4.21 \%$ \\
\hline & 1 & Byfie & & \\
\hline & 1 & Kadirty & & \\
\hline & 1 & Peeps & & \\
\hline & 2 & The & & \\
\hline & 1 & Sisteret/Sis & & \\
\hline & 1 & Ganders & & \\
\hline \multirow[t]{2}{*}{ Code Switching } & 1 & Nahear & 3 & $1.40 \%$ \\
\hline & 1 & \begin{tabular}{|l} 
Pagforce \\
\end{tabular} & & \\
\hline
\end{tabular}




\begin{tabular}{|c|c|c|c|c|}
\hline & 1 & Nasightness & & \\
\hline Complete Change & 6 & Anda & 6 & $2.80 \%$ \\
\hline \multirow{10}{*}{ Eponymy } & 1 & Bilis Crawford & 13 & $6.07 \%$ \\
\hline & 1 & Farra Faucet & & \\
\hline & 2 & Hagardo Versosa & & \\
\hline & 1 & Jano Gibs & & \\
\hline & 1 & Luz Valdez & & \\
\hline & 1 & $\begin{array}{l}\text { Nagpapajulie Yap } \\
\text { Daza }\end{array}$ & & \\
\hline & 1 & OA Delas Alas & & \\
\hline & 3 & Rica Peralejo & & \\
\hline & 1 & Sa Catriona & & \\
\hline & 1 & Stress Drilon & & \\
\hline \multirow[t]{21}{*}{ Invention } & 1 & Baler & 36 & $16.82 \%$ \\
\hline & 1 & Bongga & & \\
\hline & 1 & Chaka & & \\
\hline & 3 & Chararat & & \\
\hline & 7 & Chika & & \\
\hline & 1 & Here anda there & & \\
\hline & 1 & Krung-krung & & \\
\hline & 1 & Lafanf & & \\
\hline & 1 & Matigok & & \\
\hline & 1 & \begin{tabular}{|l|} 
Nachika \\
\end{tabular} & & \\
\hline & 4 & Nota & & \\
\hline & 1 & Otoko & & \\
\hline & 1 & Pakiyeme & & \\
\hline & 1 & Plangak & & \\
\hline & 3 & Wit & & \\
\hline & 1 & Wiz & & \\
\hline & 3 & Jowabells/Jowa & & \\
\hline & 1 & Jowala & & \\
\hline & 1 & Lafangers & & \\
\hline & 1 & Mudrakels & & \\
\hline & 1 & Chikaness & & \\
\hline Onomatopia & 1 & Ching chong & 1 & $0.47 \%$ \\
\hline \multirow[t]{2}{*}{$\begin{array}{l}\text { Phonemic Association to } \\
\text { call out Existing Word }\end{array}$} & 1 & $\begin{array}{l}\text { Antibiotic } \\
\text { (concept = } \\
\text { against })\end{array}$ & 13 & $6.07 \%$ \\
\hline & 1 & $\begin{array}{l}\text { Channel (brand = } \\
\text { fashion line) }\end{array}$ & & \\
\hline
\end{tabular}




\begin{tabular}{|c|c|c|c|c|}
\hline & 2 & Crayola & & \\
\hline & 1 & Deadmathology & & \\
\hline & 1 & $\begin{array}{l}\text { Earth ko (concept } \\
=\text { world) }\end{array}$ & & \\
\hline & 1 & $\begin{array}{l}\text { Elsa ka (movie } \\
\text { character = } \\
\text { beautiful) }\end{array}$ & & \\
\hline & 1 & Givenchy & & \\
\hline & 1 & $\begin{array}{l}\text { Ice ice bay (song } \\
=\text { someone } \\
\text { special) }\end{array}$ & & \\
\hline & 1 & Inlababo & & \\
\hline & 1 & Nadedo & & \\
\hline & 1 & $\begin{array}{l}\text { Pranelang pranela } \\
\text { (concept = } \\
\text { paranoid) }\end{array}$ & & \\
\hline & 1 & Puritang purita & & \\
\hline \multirow{4}{*}{$\begin{array}{l}\text { Recontextualization of } \\
\text { word }\end{array}$} & 1 & Bet & 11 & $5.14 \%$ \\
\hline & 3 & Kembot & & \\
\hline & 4 & Keri & & \\
\hline & 3 & Knows & & \\
\hline \multirow[t]{9}{*}{$\begin{array}{l}\text { Repetition of Misanalyzed } \\
\text { Form }\end{array}$} & 1 & Care na care & 10 & $4.67 \%$ \\
\hline & 1 & Cold cold & & \\
\hline & 1 & Dinodoing & & \\
\hline & 1 & Fight fight fight & & \\
\hline & 1 & Fly fly & & \\
\hline & 1 & Pak na pak & & \\
\hline & 1 & Super duper & & \\
\hline & 2 & Sing song & & \\
\hline & 1 & Anyare & & \\
\hline
\end{tabular}




\section{Appendix C \\ CODES AND TRANCRIPT OF INTERVIEW}

\section{Trancribed conversation}

\section{COVID-19}

Student 1: Gosh baks, ang cold cold heresa Majayjay daig pa ang Baguio dai. Feelingnessko tuloy mag-snow na. Student 2: Teh akes din. Hirapnessmakasleepsa gabi teh. Ilang patong ang kumotnessko to iwas iwas sa cold pero wa-effect.

Student 3: Kala ko nga magporoduce na ng ice ice baby ang hand ko sa super cold. Student 4: Ay! Elsa ka girl?

Student 1: Hoy pero to be honest ha, inubo talaga kobaks nasusuffocate ang ganders koteh!

Student 3: Duh, kalanessko may NCOV na akes dahil sa super duper ubo ko last time! Plus sipon pa hays.

Student 4: Talamakers pa naman ang virus naites! I'm so scared nga ih. Konting ubo lang ng taoness sa surrounding ko feel ko infected ang mga bakla!

Student 2: Huy mga beks alam nyo ba yung chika nanagspespread thru internet?

Student 1: Ano ang chikaness mo te.

Student 2: Hay kakastress mga beks, kalerky! Dami na daw nadededo sa nCov na ites!

Student 4: Ay oo teh nachika na sa'kin yan. Pati ditey nakaabot na yan!

Student 3: haykakalurky! Takot na nga jumonta mga people of the Philippines sa kamaynilaan dahil diyan.

Student 1: Ay correct ka jante! Hagardo versosa na nga mga tao, mapa otoko man, baklush, shimbolibambolchi, o kaya ba gurl sa kakathink jan.

Student 2: All over the news te!

Student 4: Kaloka! Anek ang dinodoing ng ating pamahalaan about ditey?Waley diba!

Student 3: Kalerky! Ang rica peralejo din ng mga singkit naitez! Naka fly-away agad from their inang bayan para maka avoid sa virus na itech.

Student 1: Syempre mga Farrah Faucet din yang mga yan!

Student 4: Pranellang pranela na din akes eh! Hays! Masyado kasing appreciated ni Amang hari Duterte ang China mga beks! Kaya di agad nag made action namagtravel ban. Student 2: Ay correct! Antibiotic ang mga people with super powers.

Student 1: Pero yung ibang people super ang mura sa ating pangulo ah! Yung iba napakajonggoloids! Mga antipatika!

Student 2: Wit lang mga bes, anes ba kasi ang pinananggalingan ng virus na itech?

Student 1: Ang knows ko may nay nagsspread na it is from eating bat soup daw like its so kadirty!

Student 3: Ay tei know that din.

Student 4: Yung friend ko nga mga beslalu, konting kembot na lang pajonta na sa hukay niya eh.

Student 1: Layuan mo yang friend mo teha.

Student 3: ay baks anyare sa voice mo? Baka sintomas na yan ng NCOV ha?

Student 1: Ay! OA delas alas ka bakla ha! So anes nga talaga ang symptoms ng virus naites? 
Student 2: Naread ko sa news te, ang sabi may high fever daw then runny nose and a general feeling of unwell daw.

Student 3: Diyos kogurl, katakot ha! Parang end of the world na eh!

Student4: Tapos mga baks yung mask sold out na from different tindahan, like kalurky!

Wala naakes mabili paano na ang health ko mga dai! Ayaw ko pa matigok.

Student 2: Ay ako may mask pa, givenchykita te.

Student 1: Pero teh, nanotice ko lang ha, yung ibang people of the world di agreeness sa pagforce quaratine ha like teh! Its for our safety.

Student 3: Ay nahear ko yan teh, itech ba yung mga filipinos na galing from China ba teh?

Need lang nila magparticipate for the safety of the peeps.

Student 2: Then ang sangkabaklaan nagiging racist na. Kaloka mga ites! Isisiness ba naman ang virus sa mga singkit na galing sa bansang Tsina. Diyos ko te! Jumijinit ang ulo ko.

Student 4: Ay tamaness ka jan. Hindi right yon baks. Dapat virus ang kinaiinisan at hindi ang mga singkit na ites.

Student 1: Pak na pak! Kala mo naman talaga may pakeness sa fellow peeps hays. Ay may chika pa ko. Ang Rica Peralejo ng China, hindinagpapajulie yap daza!

Student 2: itey ba yung hospital napinabuild within 10 days teh?

Student 3: Ay oo! Ang rich rich talaga ng bansang yon.Bilis crawfordtalaga kumilos ng mga chingchong.

\section{SCHOOL WORKS}

Student 2: Ay may chika nanaman si mamsh.

Student 1:Vakla may chika ako sayo!

Student 2 :Mamshano bang chika mo diyan?

Student 1: Ghorl stress drilon naaketch sa mga pinapagawa sa school.

Student 2: Ako nga din Hagardo versoza na ang beauty ko sa dami ng pakiyeme ng school.

Student 3: Crayola nadin wallet ko. Givesung nalang ako ng givesung ng Anda para sa sa mga project. Anda here anda there anda everywhere, di naman ako rica paralejo na sobrang daming anda.

Student 4: Mama, nakakashonget pag puro study, 48 years nako julat ng julat muka nakong cheapangang bakla.

Student 1: Wala nakong time para saboylet. Di nadin ako maka lafang dahil sa research. Diyos kopuritang purita nako.

Student 4: Crayola to the max nako. Deadmatology na pagpapaganda di nako maka chika sa ibang friends ghorl. Jombag najombag na braincells ko.

Student 2: Wit ko na ma see pudrakels at mudrakels ko sa balur dahil sa projects nay an kaloka.

Student 3: Wit na diko na talaga keri. Mukang luz valdez na talaga ko sa school. Student 4: Vaklang to! Keri yan mamakalukaditang kiyeme to. School lang yan bakla tayo.

Student 1: Wait anez pa meng chika mga mama!

Student 3: O ano nanaman yang kavaklaang yan! 
Student 1: Nakakaloka mag dance dance para sa grade ha. Wiz ko na knows mag teach ng steps mama. Kembot here kembot there, bistado ang mga shumintang classmates.

Student 2: Yung singsong pa mama! Knows naman nilang diko kerimag singsong ghorl, nota nota

lang. Nako jujutok na ulo ko sa stress. Eto kakanta ako ng aketch ay may lobing pakinggan niyo ha. Aketch ay may lobing flylalu sa heaven witchekels ko na nasightness jumutok lang pala, sayang lang ang anda pinang buysung ng lobing kung lafangerts sana nabusog pa aketch.

Student 3: Bet ko yang kanta mo.

Student 4: Mama ha nota notalang dapat jano gibs na givs mga bakla ha.

Student 3: Nako mag eend din ang paghihirap natin mga mamsh. Di naman magshoshogal yan ako pa ma dhokot no.

Student 1: Gora gorl fight fight fight lang. Fly flyna meh mga mama ha.

Student 2: Gora na mga sisteret!

\section{LOVE}

Student 1: Mga mamshie what's happening in this Earth?

Student 2: Anetch nanaman mamsh?

Student 1: iniwan ako ng jowabels ko. Actually di ko pala siya jowabels, kala ko lang. Inignore niya ko, alam niyo ba yun mga mmashie? Pagtapos ko siyang bilhan ng waiter sa canteen, sinupurtahan ko siya sa mga jasketball nilang laro. Tapos jinujunasan ko pa siya ng mga pawis niya.

Student 2: Kabog naman pala mamshie may pa ganon.

Student 1: Hay mamshie alagang alaga sakin yung jowako.

Student 2: Ay care na care mamsh.

Student 1: Yah. Kaso mamshie diko pala alam na may chararat siyang babae.

Student 2: Ay my god sis!

Student 1: Nako mamshie, kabog na kabog yung face ko. Di ko alam yung gagawin ko, pinahiya niya ko sa mga tropa niyang lalake, sa mga boylets na yon. Sabi ba naman sakin ang Chararat ko daw!

Student 3: Ay nako nakakaloka namna yung lalaking yon.

Ganern naman talaga yung mga lalaki eh. Pero akin iba yung boylets ko. Mahal na mahal ako.

Student 2: Antaray ni bakla!

Student 1: Pero mamshie mahal ko rin yung baby ko. Kaso, ayaw niya sakin mamshie.Alam mo yun? Jiniwan niya kosa heaven.

Student 2: Ang bobo mo namna sis. Bakit di mo pa jiwan sa ere yang lalaking yan?

Student 3: Shushunga shunga ka talaga sis.

Student 2: Oo nga.

Student 1: Eh kase mamshie Papa P siya eh.

Student 3: Dapat kase yung mga hinahanap mo yung mga chaka nalang, wag kana maghanap ng chopopo kung di ka naman din nila mamahalin.

Student 2: Plangak!

Student 1: Nako mamshie ewan ko ba sa mga boyoet na yan di sila makuntento sa catriona katulad ko. Hay nako, kailan kaya ako makakakita ng Mr. Right? 
Student 4: Andiyan naman si Lorenz diba? Yung andiyan sa room 2?

Student 2: Oo nga mamsh, crush mo yun diba?

Student 1: Di ko nga alam kung kabog ba yung face ko sakanya mamshie eh. Natatawa nalang ako kapag nakikita ko siya, kase di ko na talaga alam yung gagawin ko mamshie eh. Natatawa nalang ako sa mga pinaggagagawa ko mamshie eh para akong nababaliw sakanya.

Student 2: Ay warlang warla ang mamshie!

Student 3: Inlababo kalang talaga sis.

Student 2: Oo nga mamsh krubg krung.

Student 1: Syempre mamshie inlove eh. Di ko alam mamshie bakit ganun ginawa ko namna lahat para saknya diba? Bakit jiniwan niya parin ako?

Student 2: Jinawa mo ba yang assignment?

Student 1: Oo mamsh eh. Pinagjulat ko pa siya ng mga assignments niya. Tapos mga project mamshie.

Student 2: Nilibre mo ba sa canteen bakla?

Student 1: Nako mamshie ubos na ubos nga yung baorn ko sakanya eh.

Student 4: Nako nagpakagastos ka sa lalaking yun?

Student 1: Di ko na talaga alam mamshie eh. Pag nandiyan siya nag-iiba yung takbo ng Earth ko.

Student 2: Woah slow motion bakla?

Student 1: Yes mader. Parang yung kay Kathrine at yung kay... Sino nga yung kapartner ni Kathrine?

Student 3: Si James Reid.

Student 1: HIndi si James Reid yun mader.

Student 2: Bakla si Daniel Padilla bakla.

Student 1: Ayun si Daniel Padilla mader. Yung... yung bumabagal yung jikot pag nakikita mo siya.

Student 2: Ay ang bongga naman.

Student 1: Parang ganung yung nangyayari sakin mader pero sakanya ata parang jowala lang ako. Jinejerahan niya lang ako mader.

Student 3: Mga mars andito na yung boyfie ko.

Student 1: Ay ang haba ng hair mo ghorl ah.

Student 3: Sige chanelmuna ako sainyo.

Student 2: Nakabingwit ng Papa P.

Why do you use gay lingo? What is the purpose of using the language?

\begin{tabular}{|l|l|l|}
\hline Informant ID & \multicolumn{1}{|c|}{ Response } & \multicolumn{1}{c|}{ Code } \\
\hline IN1 & $\begin{array}{l}\text { For me, the purpose of using gay lingo is that it } \\
\text { serves as our identity, it helps is be distinct with } \\
\text { other people and through this we could identify } \\
\text { ourselves and our kind. }\end{array}$ & Serves as identity. \\
\hline IN2 & $\begin{array}{l}\text { I use gay lingo because I believe that is the way } \\
\text { to proof myself that I'm belong in that } \\
\text { community. }\end{array}$ & $\begin{array}{l}\text { Proof that they } \\
\text { belong in that } \\
\text { community. }\end{array}$ \\
\hline IN3 & Gay Lingo is another way of communicating to & Way to freely \\
\hline
\end{tabular}




\begin{tabular}{|c|c|c|}
\hline & $\begin{array}{l}\text { others (gay person or straight). We use the } \\
\text { language as our mother tongue because we can } \\
\text { easily communicate w/ each other in any } \\
\text { topic/discussion we want to have w/o thinking } \\
\text { other person will judge us. In short, it is our } \\
\text { way to freely express ourselves, because we all } \\
\text { knew the fact that other people are close- } \\
\text { minded and sensitive, so they might get } \\
\text { offended if we talk straight or bluntly the } \\
\text { language so to avoid such incidents we used } \\
\text { Gay Lingo. }\end{array}$ & express themselves. \\
\hline IN4 & $\begin{array}{l}\text { I use gay lingo to express myself more as an } \\
\text { individual considering that I am a homosexual. } \\
\text { There are some words that we think are } \\
\text { "understatements" to what we think its true } \\
\text { meaning are. I think it is best to use gay lingo to } \\
\text { hide some conversation to other people who do } \\
\text { not use it. }\end{array}$ & Understatements. \\
\hline IN5 & $\begin{array}{l}\text { Basically, as a gay I just want to be true to } \\
\text { myself and by using the gay lingo I express } \\
\text { myself more, I express my true personality. } \\
\text { I must say, as a gay I use gay lingo to make the } \\
\text { tone of the sentence as light, and enjoyable as } \\
\text { possible, since the basis of the vocabulary are } \\
\text { mostly made up with imagination for fun that } \\
\text { has made to bridge one another as a mean of } \\
\text { communication. } \\
\text { I think the purpose of using this language is that } \\
\text { to respect other people when gays are having a } \\
\text { conversation specially when it comes to the } \\
\text { person with "virgin ears" and also as I observe } \\
\text { the purpose of using "gay lingo" in social media } \\
\text { it serves as a disguise to their own opinions } \\
\text { especially during this crisis held by the terror } \\
\text { bill passed by the government. The other } \\
\text { purpose is that to fulfill the happiness of an } \\
\text { individual through that language. }\end{array}$ & $\begin{array}{l}\text { To make the tone of } \\
\text { the sentence as } \\
\text { light, and enjoyable } \\
\text { as possible. }\end{array}$ \\
\hline IN6 & $\begin{array}{l}\text { I use gay lingo to express my social and } \\
\text { personal relations, to represent an experience, } \\
\text { and to show my identity. } \\
\text { The purpose of using this language is to make it } \\
\text { easy for people of that orientation to recognize } \\
\text { each other, we love to use colorful words to } \\
\text { hide real meanings, and making people laugh } \\
\text { out loud. }\end{array}$ & $\begin{array}{l}\text { Love to use colorful } \\
\text { words to hide real } \\
\text { meanings, and } \\
\text { making people } \\
\text { laugh out loud. }\end{array}$ \\
\hline IN7 & As a part of LGBTQ, using gay lingo in every & To convince \\
\hline
\end{tabular}




\begin{tabular}{|c|c|c|}
\hline & $\begin{array}{l}\text { conversation is a part of my everyday life. I'm } \\
\text { using that kind of language because I am } \\
\text { comfortable with it. By using it, I can say that I } \\
\text { am not someone who is a hypocrite in the } \\
\text { society, in short I am true and I give voice for } \\
\text { myself. I also use it so that those undeniably } \\
\text { gays who are afraid to show their true colors } \\
\text { will have the courage to spread their wings } \\
\text { when they hear me using the gay lingo. So in } \\
\text { all, its a matter of inspiring others through this } \\
\text { language. } \\
\text { The purpose of this language is to convince } \\
\text { everyone that using Gay Language is not } \\
\text { something to be ashamed of. It is a part of } \\
\text { community and we hear this language } \\
\text { everywhere that even women use it. By using it, } \\
\text { we can express our true selves. Well for me, it } \\
\text { is advantageous. For example, when a person } \\
\text { and his gay friends are talking in public and } \\
\text { their topic is quite sensitive to others, they can } \\
\text { use gay language therefore; other people around } \\
\text { them will not understand what they are } \\
\text { babbling. They no longer need to be in private } \\
\text { places to discuss something sensitive. Hence, } \\
\text { gay language added a fruitful taste in every } \\
\text { day's life of those who use it. }\end{array}$ & $\begin{array}{l}\text { everyone that using } \\
\text { Gay Language is } \\
\text { not something to be } \\
\text { ashamed of. }\end{array}$ \\
\hline IN8 & $\begin{array}{l}\text { I use gay lingo just as a preference so I can } \\
\text { show others who am I as a person without } \\
\text { pointing it out for them. } \\
\text { Technically speaking, it doesn't have a very } \\
\text { definitive purpose. It is just there to show what } \\
\text { a distinct character a person has; furthermore it } \\
\text { was created so members of the LGBTQ+ } \\
\text { community can speak with each other as means } \\
\text { of identity. }\end{array}$ & $\begin{array}{l}\text { Show what a } \\
\text { distinct character a } \\
\text { person has. }\end{array}$ \\
\hline IN9 & $\begin{array}{l}\text { I use the gay lingo because for me it is a form } \\
\text { of expressing my identity as a part of the } \\
\text { LGBTQ community. It's just something that } \\
\text { forms bonds or connections with my fellow } \\
\text { LGBTQ members. Also that this particular } \\
\text { language does not have boundaries or set of } \\
\text { rules with regards the usage of such, we can use } \\
\text { it freely. And most importantly, we can } \\
\text { showcase the richness in creativity of our } \\
\text { community, in such way that we can truly } \\
\text { uncover our genuine identity. }\end{array}$ & $\begin{array}{l}\text { Forms bonds or } \\
\text { connections with } \\
\text { my fellow LGBTQ } \\
\text { members. }\end{array}$ \\
\hline
\end{tabular}




\begin{tabular}{|c|c|c|}
\hline & $\begin{array}{l}\text { The purpose of using this language is not only } \\
\text { to feel our freedom as LGBTQ members. But } \\
\text { also to break the barriers that confine not only } \\
\text { the members of this particular community but } \\
\text { everyone in the society. It destroys the barrier } \\
\text { that separates the community to the society and } \\
\text { liberates the society from the dominance of } \\
\text { hatred to foster respect and acceptance with the } \\
\text { community. This aims to develop an affinity } \\
\text { between persons. And promotes equality } \\
\text { despite our individual differences that everyone } \\
\text { can live in their own choices and preferences. }\end{array}$ & \\
\hline IN10 & $\begin{array}{l}\text { I used this gay language because it defines me } \\
\text { as who I am. It is merely accepted both gays } \\
\text { and non gays as an expression as well, it serves } \\
\text { as an armor to shield ourselves from chasm and } \\
\text { social stigma caused by gender differences. I } \\
\text { used this way of speaking to recognize each } \\
\text { other. }\end{array}$ & $\begin{array}{l}\text { Merely accepted } \\
\text { both gays and non } \\
\text { gays as an } \\
\text { expression as well. }\end{array}$ \\
\hline IN11 & $\begin{array}{l}\text { I use gay lingo as language for easily } \\
\text { understand and communicate with my fellow } \\
\text { gay because we have the same gender } \\
\text { preference. Sometimes we use it for fun and as } \\
\text { metaphor in addressing it to other. }\end{array}$ & $\begin{array}{l}\text { Use it for fun and as } \\
\text { metaphor in } \\
\text { addressing it. }\end{array}$ \\
\hline IN12 & $\begin{array}{l}\text { I usually use gay lingo in communication to } \\
\text { hide the explicit content of our conversation to } \\
\text { others who don't understand our language. I } \\
\text { only use gay lingo if I'm talking to my gay } \\
\text { friends but not in front of person who don't use } \\
\text { it. I think that is rude and unethical. }\end{array}$ & $\begin{array}{l}\text { To hide the explicit } \\
\text { content of our } \\
\text { conversation. }\end{array}$ \\
\hline
\end{tabular}




\section{Appendix D \\ DOCUMENTATIONS}

Plagiarism Detector v. 1652 - Originality Report 24/06/2020 10:24:57 AM

Analyzed document: Rubiales_LINGUISTIC DEVIATION OF SWARDSPEAK TO GAY STUDENTS ENGLISH LANGUAGE COMPETENCIES_3.docx Licensed to: Rainelle Romero Comparison Preset: Rewrite. Detected language: English

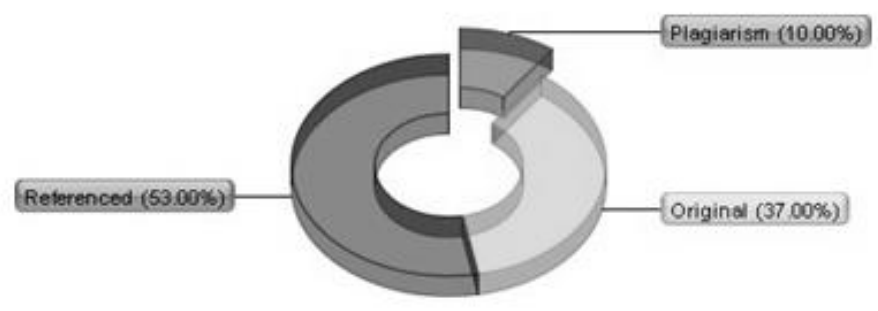

Distribution graph:

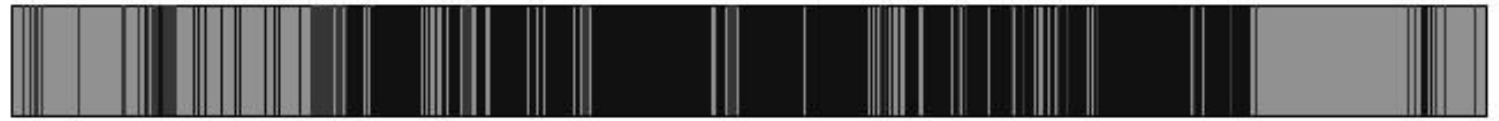

Top sources of plagiarism:

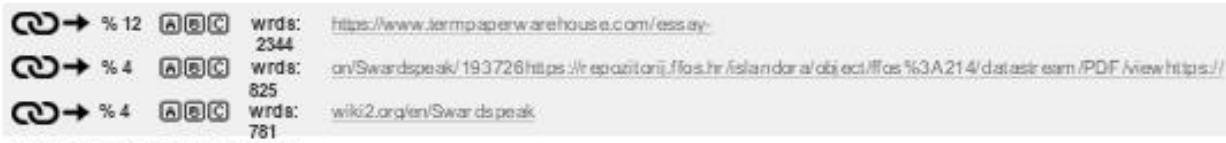




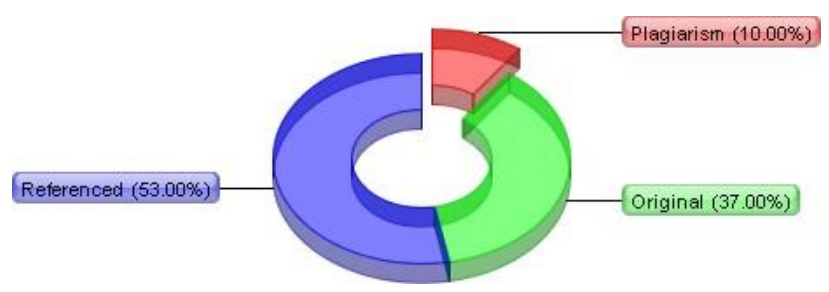

Distribution graph:

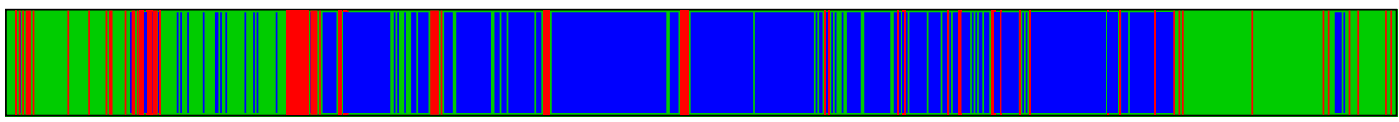

Top sources of plagiarism:

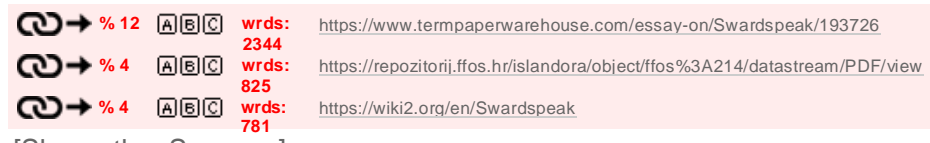

[Show other Sources:]

Processed resources details:

[Show other Sources:]

$$
186 \text { - Ok / } 42 \text { - Failed }
$$

\section{Important notes:}

\begin{tabular}{|c|c|c|c|}
\hline Wikipedia: & Google Books: & Ghostwriting services: & Anti-cheating: \\
\hline [not detected] & [not detected] & [not detected] & [not detected] \\
\hline
\end{tabular}

Active References (Urls Extracted from the Document):

No URLs detected

\section{Excluded Urls:}

1. wikipedia

\section{Included Urls:}

No URLs detected

Detailed document analysiS

Chapt

er 1 INTRODUCTION

Language

through instrument in moving forward the students' competencies can be utilized by the society as a implies to preserve sexual orientation disparity, through control relations, which is both oppressive and onerous. As numerous clients of swardspeak may contribute to the improvement of a dynamic dialect, it can be a figure to students' competencies drop (Catacutan, 2014).American language scholar J. Stephen Quakenbush

(2015) justified in an interview, about Philippines' rich languages, the increasing use of swardspeak in the society. Swardspeak is something not disturbing, like any other languages, but

should be judged based on its effectiveness among its users, and on the way people using

it communicate and express their needs. It is difficult for a non- speaker or a beginner but then its intricacies are what make this language unique.

(1706) Plagiarism detected: $0.22 \%$ https://www.termpaperwarehouse.com/... +2 resources!

Swardspeak has achieved a higher degree of acceptance in recent years in the Philippines. Both gays and nongays can be heard uttering gay expressions. But the main role of swardspeak for gay people in the Philippines is to function as an 

Sociolinguistic

Primer on

Linguistic

Deviations of

Swardspeak 


\section{INTRODUCTION}

Languages evolved and in the process of evolution, new words are formed, and others die. There are words that eventually find their way to the mainstream through popular use. Swardspeak has achieved a higher degree of acceptance in recent years in the Philippines. Both gays and non-gays can be heard uttering gay expressions.

Learners as considered millennial, exposed with technology and current trend in terms of gadget, fashion, and even language. They tend to easily acquire development around their environment. Considering the vast majority of high school students who embraced their identity affect their learning one way or another. They might intentionally acquire certain language like swardspeak, and choose not to abide by the rules of his language when he transcends its norms and exceeds the limits of the linguistic protocols that characterize it.

Modern educators must advance not just the learning materials but also the contents and approaches of language teaching. To ensure the effective teaching standards inspiring students to reach their highest potential ability, teachers need to equip their selves with the appropriate materials. 


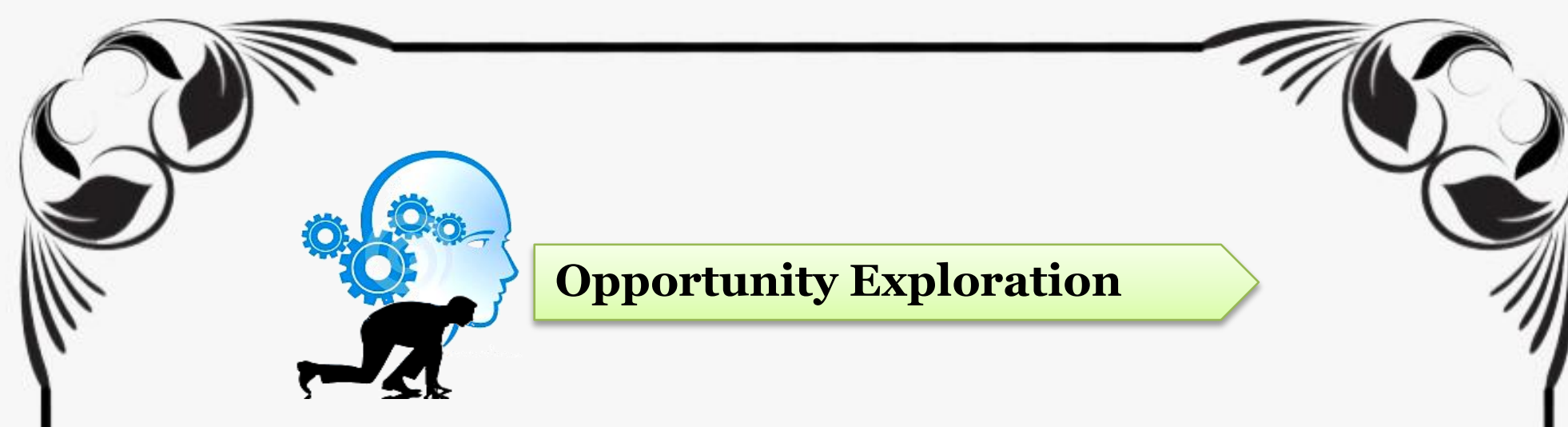

$>$ In the past quarter, have I observed my teachers-subordinates try new language teaching strategies?

$>$ What language activities suit the interest of the learners?

> Are there chances for instructional modification? Improvement?

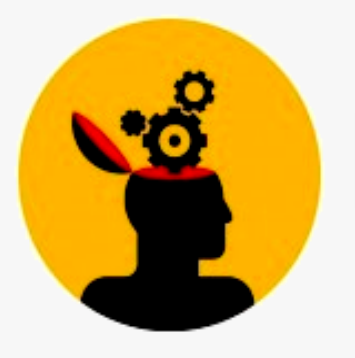

\section{Idea Generation}

Innovative Encounter.

Gather your teacher-constituents in one session of their in-service training (INSET) and ask the following:

* The language teaching approaches, methods, and/or strategies they often use;

* The language teaching approaches, methods, and/or strategies they think/see work best among their learners; and

* The language teaching approaches, methods, and/or strategies they think/see learners enjoy the most. 
Let the language teachers form small groups either accordinly their closest peers, based on the grade levels they teach in. Let them decide for the competencies, lesson objectives, strategies, materials, and assessment techniques. Allow the language teachers to think and share their proposed innovations for the language teaching strategies they have chosen. Use the suggested matrix below for your guide.

\begin{tabular}{|l|l|l|l|l|l|l|}
\hline Topic & Competencies & $\begin{array}{c}\text { Lesson } \\
\text { Objectives }\end{array}$ & Strategies & Materials & $\begin{array}{c}\text { Assessment } \\
\text { Techniques }\end{array}$ & $\begin{array}{c}\text { Proposed } \\
\text { Innovation }\end{array}$ \\
\hline & & & & & & \\
\hline
\end{tabular}

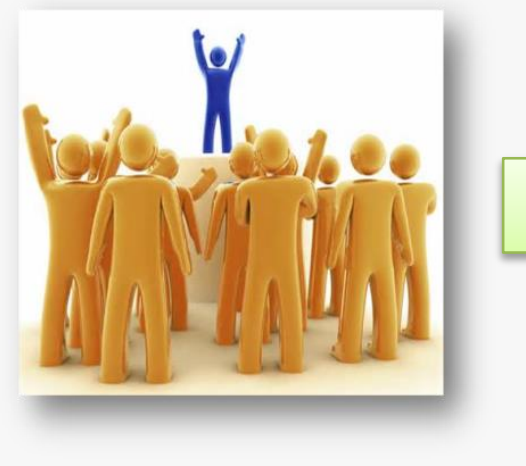

\section{CHAMPIONING}

\section{Deviation}

A linguistic deviation is a disruption of the normal process of communication: it leaves a gap, as it were, in one's comprehension of text. The gap can be filled, and the deviation rendered significant. But only if by an effort of imagination the reader perceives some deeper connection which compensates for the superficial oddity.

The element of Interest: 
A deviation first of all evokes the interest of the reader. Since

deviation is unusual use of language and expression it appears appealing as the reader finds it different. The Element of Surprise: Surprise is

experienced when the reader interprets a deviation and finds out that

what apparently appeared unbelievable and or abnormal makes sense at deeper level.

\section{Lexical Deviation}

When rules of lexis or word formation are broken such deviation is called lexical deviation. In which Neologism or invention of new words is one of the more obvious ways in which a poet may exceed the normal resources of language. According to Geoffrey Leech a more correct explanation is that an existing rule (of word formation) is applied with greater generality than its customary. Example: affixation of prefix fore to a verb. Foresee, foretell. And I Tiresias have foresuffered all (Eliot, The Wateland)

Lexical Deviation The most common processes of word formation are affixation (the affixation of prefix or suffix to an item already in language) And compounding ( the joining of tow or more items to make a single compound one) Example: The widow-making, unchilding, unfathering deeps. COMPONDING AFFIXATION 


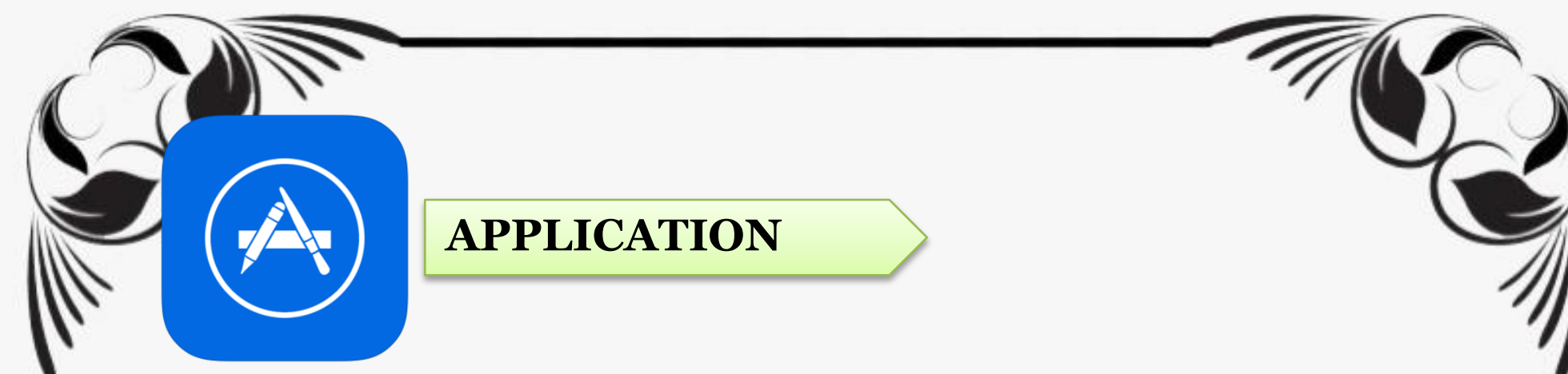

Let the language teacher to study the suggested activities for their English classes dealing with the current trend of linguistic deviation through swardspeak.

\section{SAMPLE ACTIVITY \#1}

\section{Say it with Color.}

Below are some Swardspeak you might hear everwhre. We're pretty sure you've heard a lot of these by now. If you've been wondering what they mean, look no further.

Directions: Let the students study the given swardspeak and give them time to wite their own senetences using each word. Let them present their work orally so they can practice expressing their thoughts in a creative manner. 


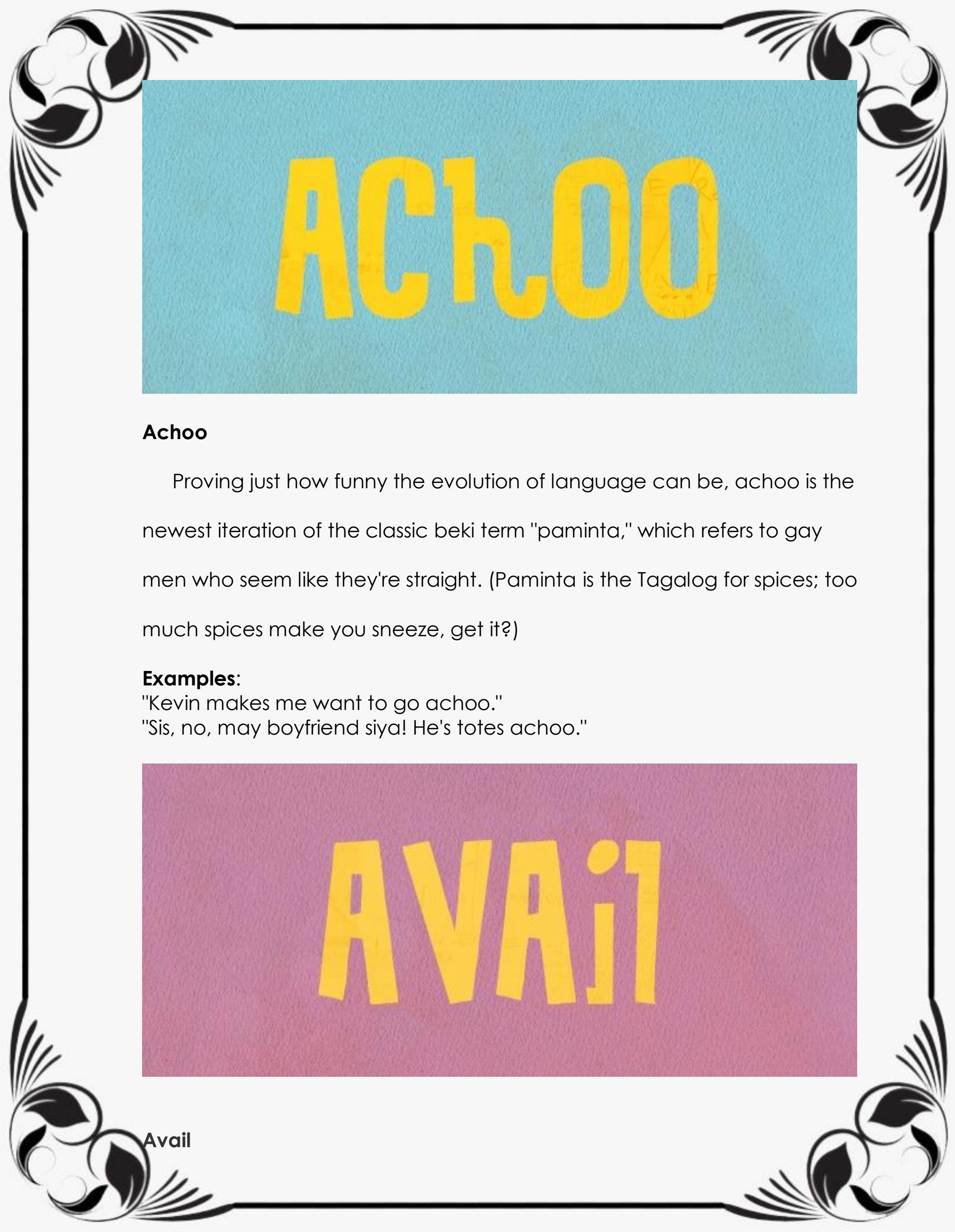


This term doesn't exactly refer to what you would ask an online shop to find out whether they still have the item you want in stock. When someone is pertained to as "avail," it simply means that he or she is someone worth pursuing or going after.

\section{Examples:}

"OMG! Cedric is so cute today! I so wanna avail."

"Yes, actually he's sobrang avail!"

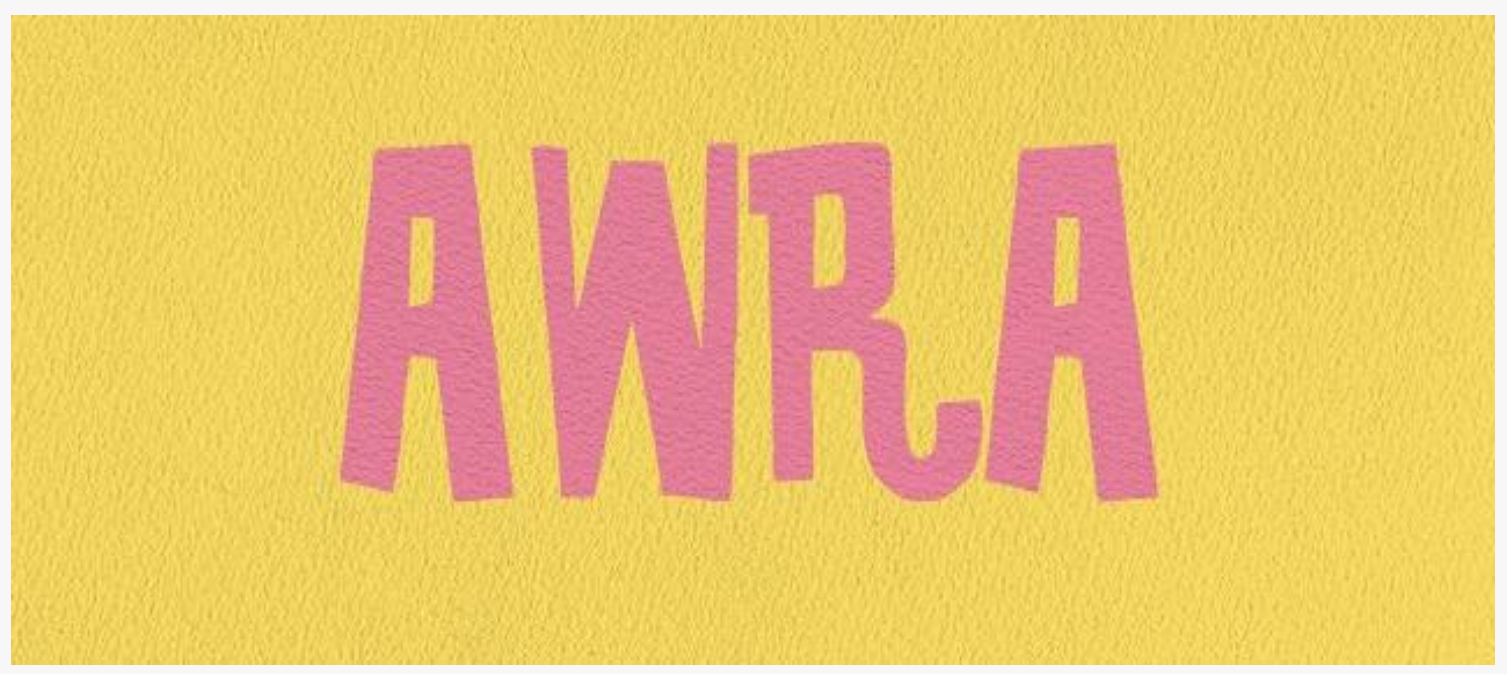

\section{Awra}

No, we're not referring to that mall in BGC_to "awra," simply put, is to attract attention, or to put the spotlight on one's self (whether it be for good or bad). When placed with the beki modifier "pak," the interjection "pak awra" can be used similarly as with the English "yaaaas, werq!"

\section{Examples:}

"Girl, I caught you making awra to the cute bartender."

"Yaaas babe, pak awra! You look gorj!" 


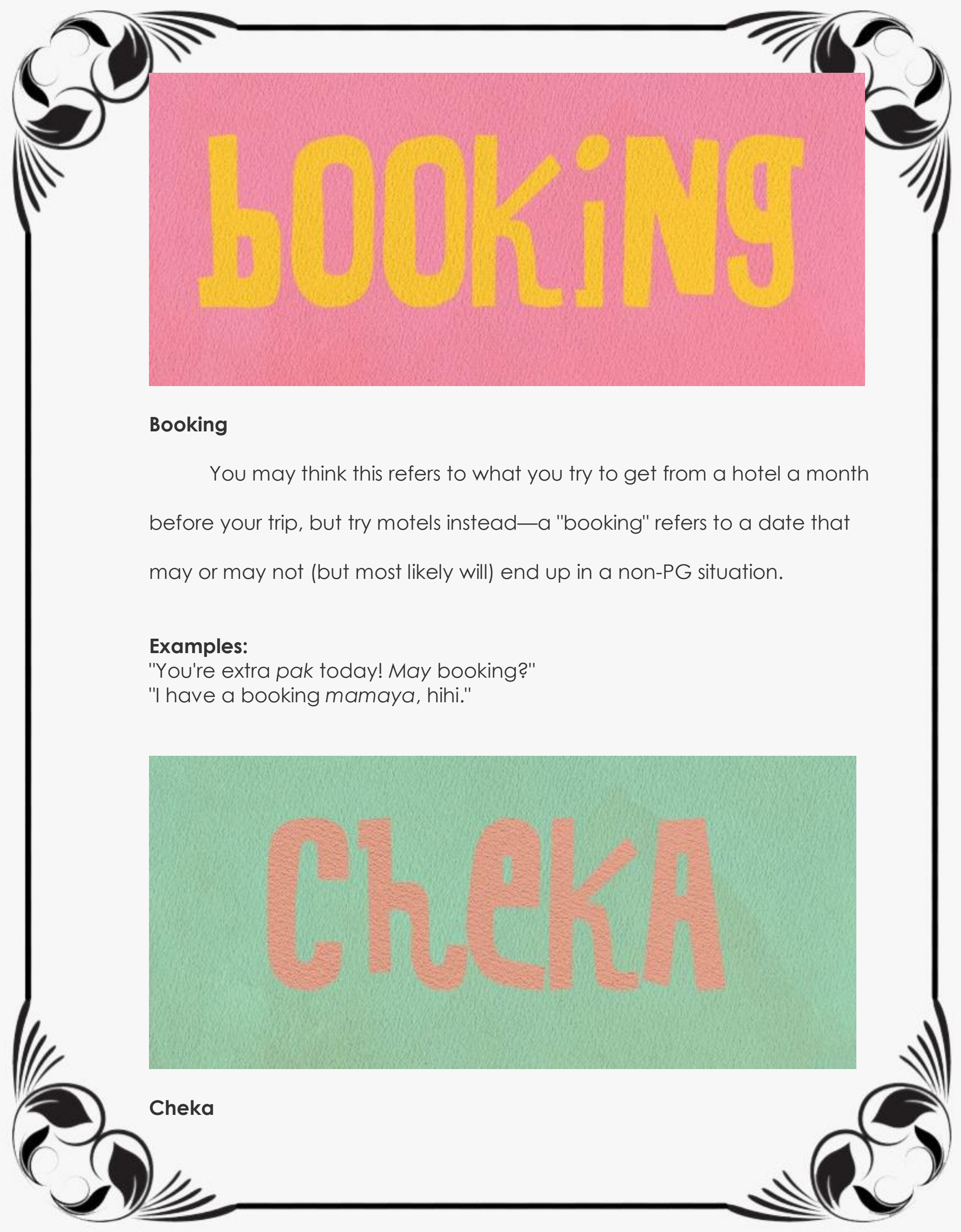


Like its older sisters "chos" and "charot," cheka can be used in of "just kidding." Alternatively, cheka is also used in lieu of "echosera," which refers to those who are delusional.

\section{Examples:}

"Sis, I love your bag—cheka!"

"Cheka siya if she thinks I care what she posts on IG."

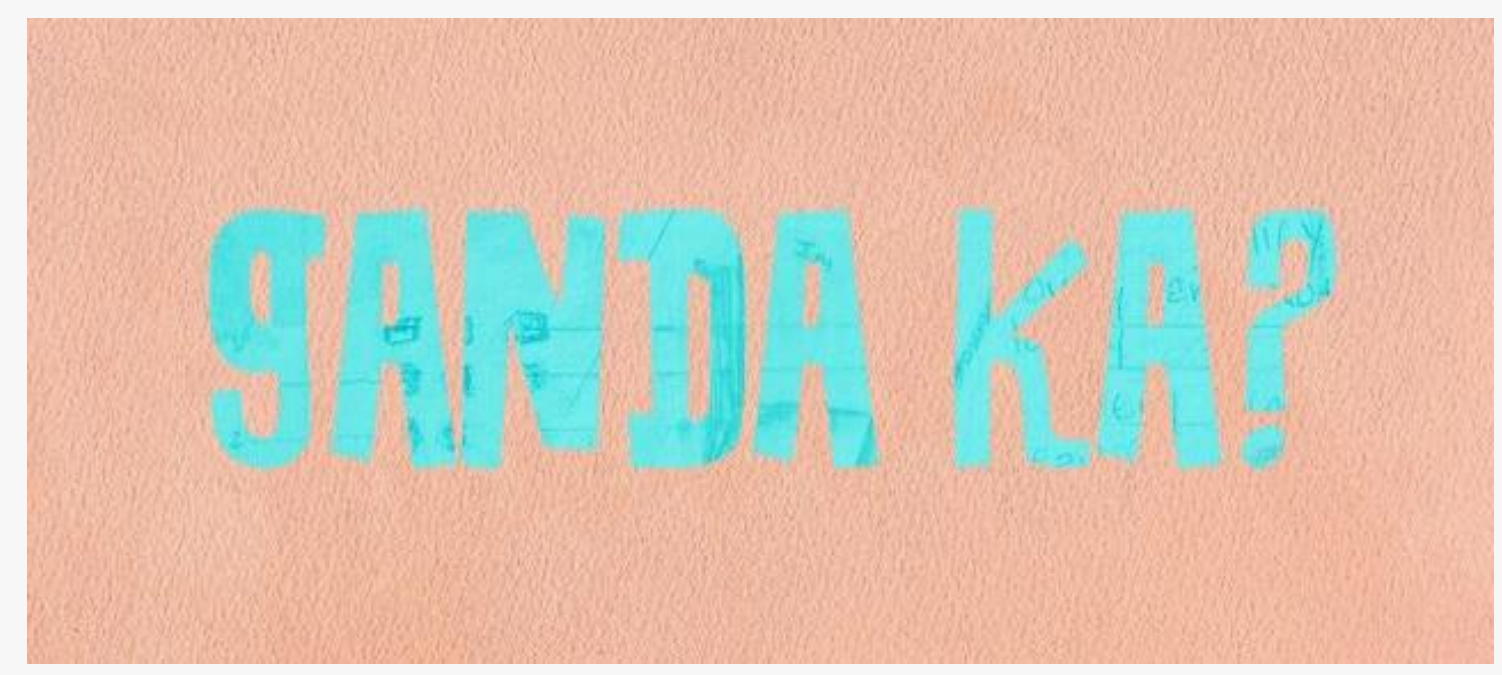

\section{Ganda ka?}

One of the few new beki slang terms that's gone mainstream

(thanks to a certain hilarious viral video), "ganda ka" is a dollop of sarcasm and shade masked as your typical compliment.

\section{Examples:}

"I saw na nilandi ka niya kanina, ganda ka?"

"Congrats on your promotion! Ganda ka?" 


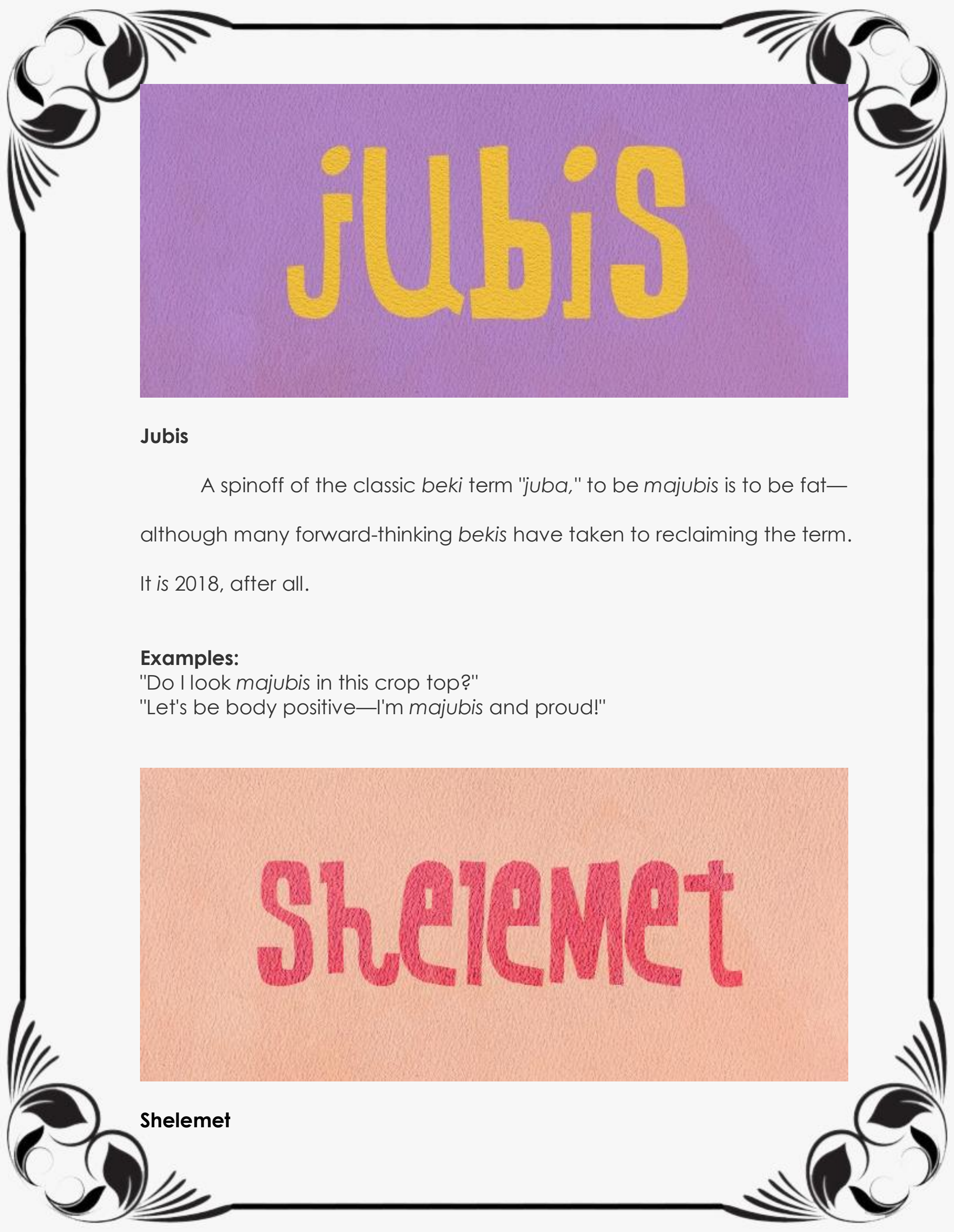


From the root word "salamat," this term simply means "thanks"

with an extra heaping of pabebe. Another beki term popularized by the

hilarious viral Mean Girls dubbed videos, use it when you want to add a pop-culture reference to a very normal conversation with your BFFs over brunch.

\section{Examples:}

"I got you that eye cream you're always hoarding."

"Oooh, shelemet."

\section{Shuta}

A combination of "shit" and "p*ta," shuta is a beki curse word that's used similarly to the word "gago"—it's said jokingly with friends as a lighthearted term of endearment, or alternatively, in a heated argument as a scathing insult.

\section{Examples:}

"Why did you tell him about our secret? Shuta ka talaga."

"I was so surprised! Shuta ka!" 


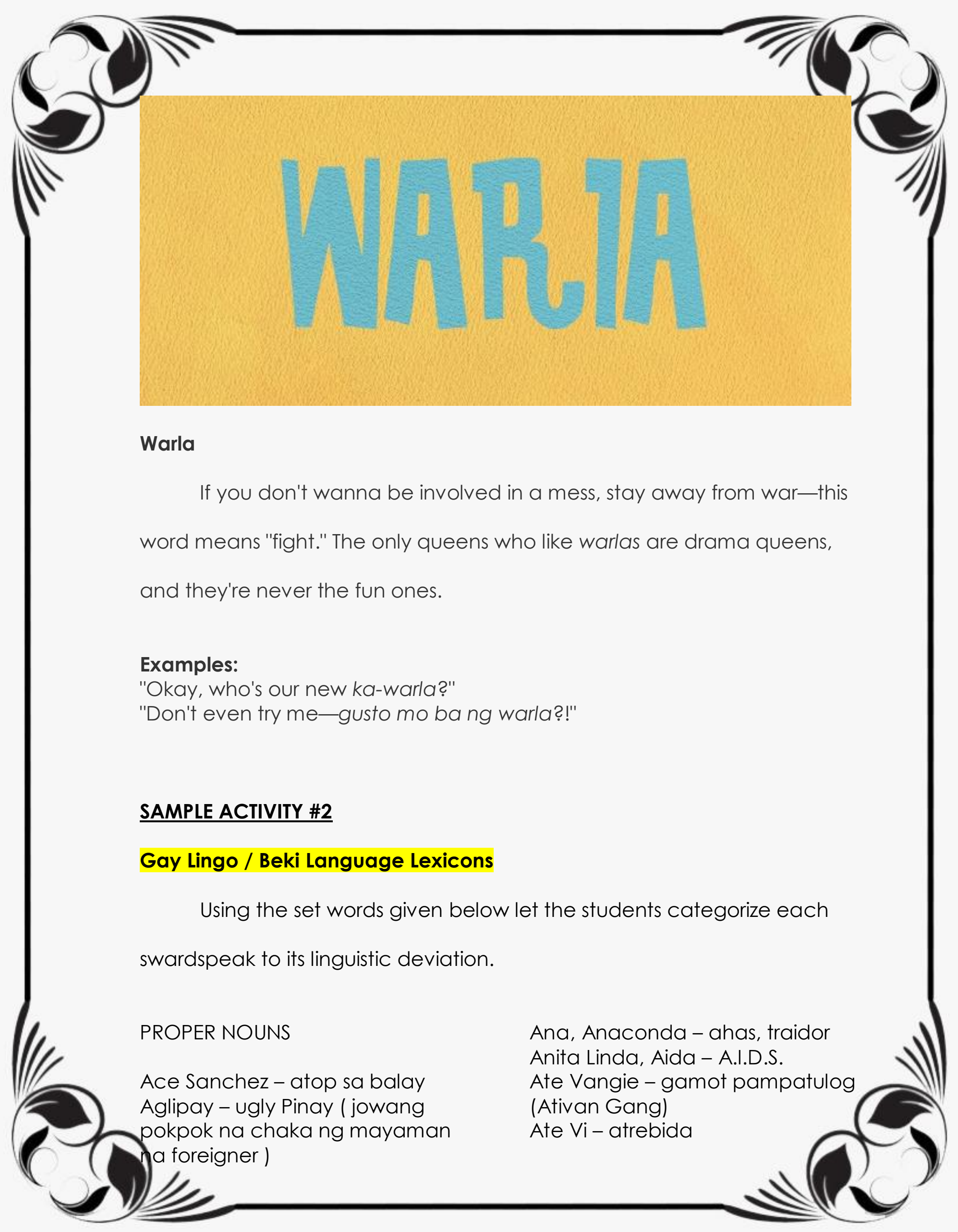


Backstreet Boys - cute guys sa likuran mo

Bayombong, Nueva Viscaya masturbate

Bebang, Mayta-maid

Blusang Itim - mga bakla na

gumanda nang maayusan sa

parlor

Cathy Santillan, Kate Gomez,

Cathy Mora, Cathy Dennis -

makati, malibog

Chabelita - chubby

Chanda Romero - tummy lang

laking Chanda Romero nung

pulis) / an old woman

Chiquito - maliit

Churchill - sosyal

Crayola Khomeni - iyak

Dakota Harrison P! laza - malaki

birdie

Debbie Gibson - give

Duty Free - maliit ang nota

Ella Mae (Saeson), Ella Fitzgerald,

Ella Luansing - state of feeling

horny

Eva Kalaw - evak

Felix Bakat - bakat ang birdie (sa

brief or pants)

Girlie Rodis - babae

Givenchy - give, pahingi

Halls - tsupa

Indiana Jones - hindi sumipot

Janjalani, Pocahontas - bakla na

palaging late o indyanera

Jennilyn (Mercado) - cheap,

chaka

Joana Paras - asawa

Julanis Morisette, Reyna Elena umuulan

Julie Andrews - mahuli

Kelvinator, Kelvina - babaeng

mataba, sinlaki ng refrigirator

Leticia Ramos Shahani - shabu

Lilet - bading na bagets
Lucita Soriano - loss na, sorryea Lucrecia Kasilag - baliw

Luz Clarita, Luz Clarita, Luz Valde - talo, loss ang beauty

Maharlika, Mahalia Jackson mahal

Miss Nigeria - negra

Murriah Carey, Morayta - mura

Nora Daza - magluto

Oprah Winfrey, O.P.M. - oh,

promise me, pangako, utang

Phil Collins - Philcoa

Purita Kalaw Ledesma, Purita

Kashiwara, Pureta Malaviga -

poor, dukha

Rica Paralejo, Nina Ricci-

mayaman

Rita Gomez - naiirita

Ruffa - laklak

Siete Pecados - tsismosa

Thunder Cats - gurang

Tom Jones, Tommy Lee Jones -

gutom

Uranus - puwet

Washington D.C. - wala

X-Men - mga dating lalaki

Yayo Aguila - dyahe

Zsa Zsa Padilla - o siya, sige!

ADJECTIVES \& ADVERBS

48 years - sobrang tagal

antibiotic - antipatika

balaj, valaj - balahura

bella - boba

bigalou - big

biway, chopopo, guash - gwapo

bongga, bonggakea - super to

the max

borta - malaki katawan

boyband - lalaking sintaba ng

baboy

buya - nakakahiya 
chaka, chuckie, shonget, makyonget, chapter, jupang-pang ugly cheapangga, chipipay - cheap, ka-cheapan

chipipay - cheap

chopopo - gwapo

conalei - baklush

daki - dako

dites - dito

doonek - doon

effem - halatang bakla

emena gushung - malanding

semenarista

fayatollah kumenis - payat

ganda lang - for free

ganders - maganda

intonses - sira, wasak

jongoloids - bobo

jowa, jowabelles, jowabella -

karelasyon, boyfriend o girlfriend

jutay, juts - maliit

kabog, loss - talo!

katagalugan - matagal

katol - mukhang katulong

kirara - pangit / maitim

klapeypey-klapeypey -

pumalakpak

krang-krang - hungry (same as

Tom Jones)

krung-krung - sira ulo, baliw

Iulu, tungril, tetetet - lesbian

mahogany, mashumers, ugmas -

mabaho

majubis - mataba / gusgusin

matod - magnanakaw

nakakalurky - nakaka-shock,

nakaka-takot

neuro - napaisip bigla, mind-

boggler

oblation - walang saplot

otoko - lalakeng lalaki

pamin, paminta, pamentos,

pamenthol - discreet gay guy pinkalou - pink

pranella - praning

quality control - maganda ang

quality

sangkatuts - marami, isang

katutak

shala - sosyal

shogal - matagal

shokot, bokot - takot

shonga, shongaers, planggana *****

shonga-shonga - *****_******

shonget, makyonget - ugly

shontis - buntis

sudems - never

tamalis - tamad

urky - nakakaloka

warla - loka-loka, nawawala sa

sarili, nababaliw

wasok - contraction ng "wasak

pag pasok"

wiz, waz - wala!

wrangler, thunder(s), tanders,

majonders - matanda

NOUNS, PRONOUNS AND

PREPOSITIONS

adez, andabelz, adesa, anda,

ka-andahan, andalucia - pera

akesh, akembang - ako

badet, dinga, dingalou - bading

berru - beer

borlog - tulog, power nap

bottomesa, bottones - a bottom

bufra - boyfriend

carrou, carosa - car

cheese - chismis

chimi, chimini, chimi-aa, chimini-

aa - maid

constru - construction worker

daot - ahas, traitor

ditey, ditich, ditraks - dito

feelanga - crush

fiampey - singit, birdie, flower 
garapata - vaklush na punggok

na majubis

gardini - security guard

oishi - shabu

gulay, pechay, bilatch, tahong -

babae

hada - oral gay sex

hammer - pakonyo effect sa

mga prosti or callboy, "pokpok"

havana - mahabang mukha

hipon - maganda ang katawan

pero panget

itich, itechlavu - ito

itich-me-how - birdie

jipamy - jeep

jowa, jowawis - lover,

boy/girlfriend

jubelita - vaklita, batang bading

kat-kat - sosyal na tawag sa

katulong

katol, chimay - katulong

kyota - bata

kyotatalet - sanggol

likil, mentos, future - lalaki

merlat, melat, bilat, mujer -

babae

nota, notes - penis

pa-uring - a bottom

performance artist - mahilig mag-

inarte

potato queen - chink for chinks

red alert - menstruation

rice queen - chink folks who go

for white guys (?)

colbam, sholbam - callboy

sholbug - na daig

shulupi - pulubi

shumod, shumodity - tams

suba, bugarou - cigarette

success story - babae/lalaki na

mukhang katulong na may lover

na foreigner na masalapi

katuray - baklang mukhang

katulong na mataray tayelz - tayo

variables - barya, coins

wigwam - wig

pandagdag Ing...

a, anda,kuray, =pera

lapz, lapangga,lapang = kain

notes, noting, , nota $=$ alam nyo na

yun

ana bet = ayaw ko, di ko feel

sunshine dizon = umaga na

nomo, mamam = inuman

borgy manotoc $=$ maraming

pimples

chanel $=$ una na $\mathrm{ko}$

mudra $=$ mama

pudra = tatay

shupatid, jupiter = kapatid

julalay - alalay

manilyn reynes - pera/ulan

junakis - anak

chaka, chapter - panget

daku, dakila - malaki

booblang, bobonicles - mahina

ang ulo

kimiladoo - kunwari lang

plastikada - plastic

bagelya - bag

afam,mering $=$ foreigner

joga boobey = boobs

silikonada $=$ baklang may boobs

warla = away

bona,bobonikles $=$ bobo

b.y, = gwapo

omz,ombaw,lulu = boys

bilat, kilatra $=$ babae

erna $=$ poo poo hehe

suba $=$ yosi

durables $=$ mura

mahalia jackson, makimils =

mahal

stuts = states U.S

aida $=$ aids

julalay - alalay

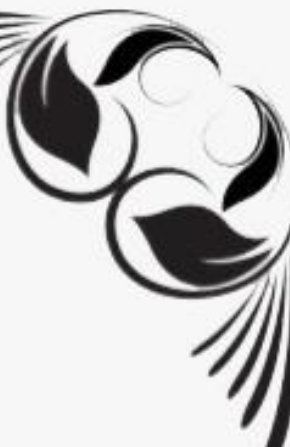


manilyn reynes - pera/ulan

junakis - anak

flangak, planggana, flatch, flat shoes - tama, korek

chaka, chapter - panget

daku, dakila - malaki

booblang, bobonicles - mahina

ang ulo

kimiladoo - kunwari lang

plastikada - plastic

bagelya - bag

okray -nasira

imbyerna - nainis

jutay -maliit

jowa -bf

Iuzvaldez -natalo

lukring -lukaluka

lafang -kumain

toyota -may sumpong

Shonga -stupid

eclavu -my love

echos -whatever

everloo -forever

yamey - means mamaya

ramsey - means pahiram o

pautang

kasbum - means bukas

kadley - means maglakad

chamita - means pangit

portugal - means ang tagal,

matagal

nagmamaasim -

nagmamaganda

eksenadora - gumagawa ng

exena

ferlie - bl*w job

lafyok - kain or torrid kiss ate madeska - madaldal

ate matet - malapad noo

ate lucky - malaki ilong

ate nancy - nonsense

ate gina - gumagawa ng kwento pangat sa ubas, pasok sa bangaexactly, korek

duty free, dyutay - maliit and

tootoot ng mga boys

wersu - boobs

werlog - balls / itlog ng boy.

(hihihi)

notes, notakels - guys genitals

sa trulilty - sa totoo lang

tusha - s3x

kebla, kebz - malaki ang

notes..wehhe

wizel, wit - hindi

atashi - ako

anda, ades - pera

francine prieto, pransya - may

toyo o may sayad sa utak.. wehhe

epek lang, keri lang - means ok

lang

cryola - iyak

erklip - tulog

ikura - magkano

embey, emberika - galit or inis

touch mobile - nahawakan

chipangga - cheap

thundercats -matanda

makiyawti-mabaho

pokish - slutty

bonamin - anal s3x

biogesic -mast*rbate

insekyora -inggitera, insecure

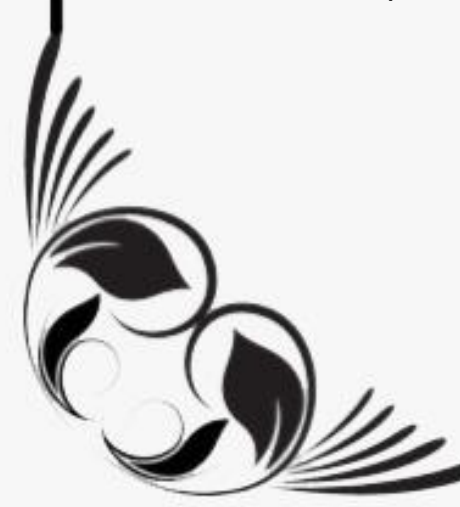




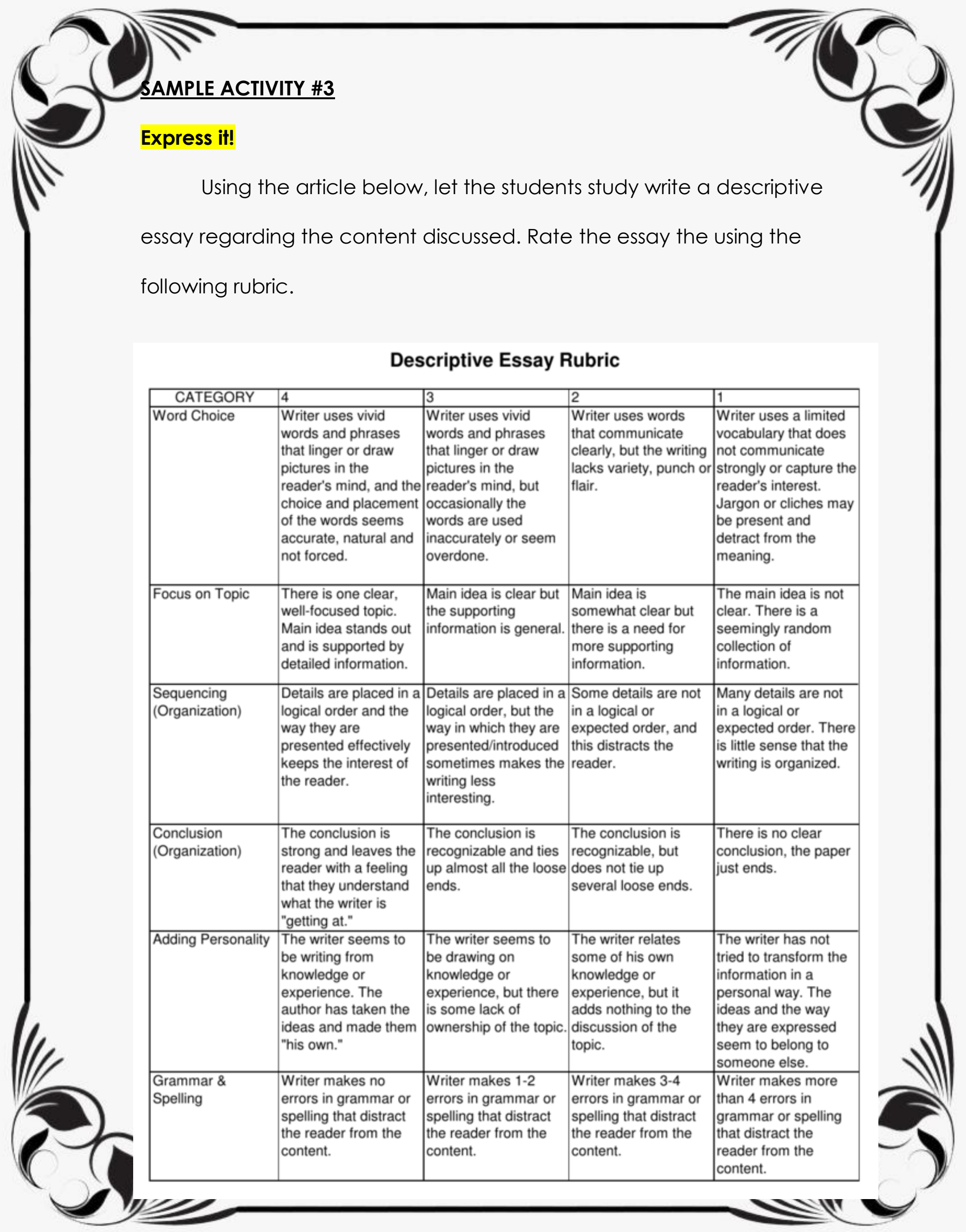




\section{Beki Lingo - Anitch Itich?}

by Ethnic Groups Philippines

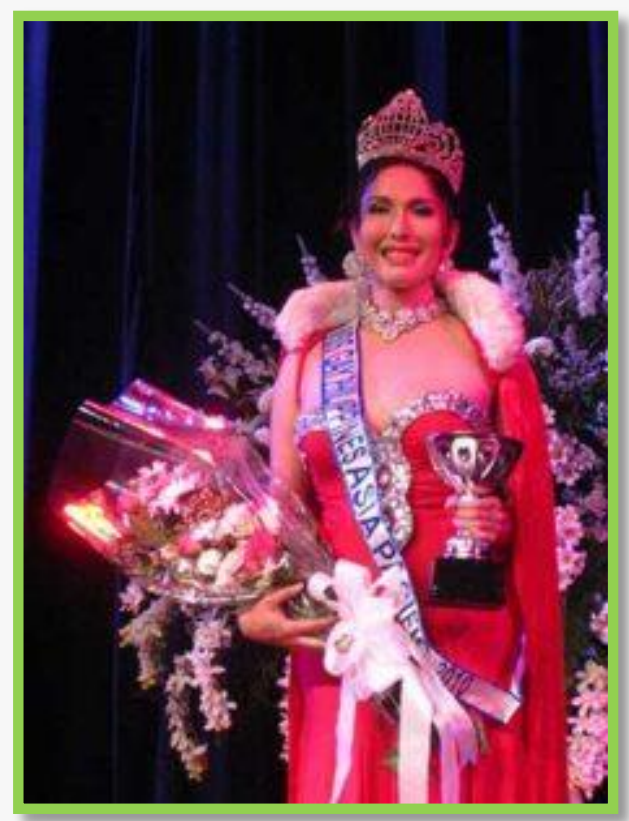

Image from Allain Angeles on Flickr 6 August 2018

Quezon City - Gora na mga sisteret!

Blurted Francine in a very casual manner whilst conversing in the beauty salon one afternoon. "Gora na mga sisteret" is a peculiar language for those unfamiliar with the Filipino gay lingo, formerly called swardspeak and nowadays known as bekimon language.

Gays in the Philippines are at present becoming more visible in the society. The constant appearances of famous gay celebrities on TV and in movies have paved the way for the Filipino audience to be more accepting of gays over the last decades. They are known to be pretty 
loud, and it's no surprise when you overhear a raucous conversation between them in busy streets, beauty parlors, or coffee shops.

Philippine gay culture prospered in the 1970s. However, it was only in 1994 that the first Metro Manila Pride March and Festival was held by the LGBT community. Back in its heyday, the Malate area in Manila was known as the gay capital, where bars that cater to gays flourished. Some even featured drag shows.

Though many of those businesses have now disappeared, one thing survived: the gays' playful yet strange language that a few of us still can't seem to grasp. The bizarre language is unrecognizable to begin with but it has since infiltrated mainstream society and is increasingly used today. Taglish (Tagalog-English) code-switching from which swardspeak arose is widely used, particularly in Metro Manila. The term derived from the word sward which is a slang for gay male and was invented by film critic and writer Nestor U. Torre in the 1970s.

Swardspeak is a coded lexicon mainly utilized by the gay community in the country. It incorporates Tagalog, Visayan, English, Spanish, and Japanese words as well as uses a variety of other sources such as celebrities, politicians, and even trademark brands. Other names used for this language include bekimon or bekinese, arising from beki, which is another colloquial term for "gay."

Below are some examples: 
Anetch - what

Washington - Nothing or none

Givenchy - to give

Enter the Dragon - come in or enter

Backstreet Boys - cute boys at the back

Bitter Ocampo (from local celebrity Diether Ocampo) - bitter or sad

Pagoda Cold Wave Lotion - tired

Award - to reprimand

Crayola - to cry

Statue of Liberty - free

Over the years, the proliferation of bekinese has become more apparent, especially among the youth and even among heterosexual males and females. Words like charot ("joke") or chaka ("ugly") are frequently heard in conversations, even in the famous war of words between two Philippine public officials in 2015. Phrases such as chus, churva, and etchus have become public expressions and are no longer restricted to just gay speakers alone.

Cristina (moniker), a 28-year-old gay who works for a BPO industry, learned the language a while back in college when his university friends would converse to each other. "I wasn't familiar with the language at the time so I observed the words used in conversation and learned from it. I 
became an expert in no time since we hang out almost every dary. Cristina claimed.

He added that the pressure of keeping up with friends and understanding them in such a way only they could understand made him eager to learn the language. "We make use of it whenever we want to talk about something private, such as the cute guys in class or secrets we don't want other people to know. The beki language gave us leverage to blatantly gossip about everything," Cristina further disclosed.

The Philippines, being a conservative country, has always been perceived as biased with regard to homosexuality. In the olden times, the notion of homosexuality was taboo and regarded as an embarrassment for the family. More recently, things have been different and gays are recognized for their unique contribution to society. Along with acceptance of the gays grew the dissemination of their once-secret language that is now being spoken and used by much of the population.

Beki language doesn't necessarily observe rules in structure as it is constantly changing and developing with new phrases added to keep up with new trends or culture. Arianna (moniker), a 20-year-old college student from Caloocan said "Every so often there are always new beki words I learn from friends since we always try to update ourselves with the current trends. We use the words too frequently that a lot of my 
classmates, both men and women, have also learned to spedk the language."

When asked what favorite beki words he likes to use in particular, Arianna added he enjoy applying names of particular celebrities such as the following:

(1) Ang laki na ng Chanda Romero ko! (My tummy is big)

(2) Hagardo Versoza na ang lola mes. (Your sister is haggard.)

(3) Alicia Mayer na akez (I am late.)

(4) Tara lafang! Tom Jones na akez. (Let's eat. I'm hungry.)

Lara, a 16-year-old female from Quezon City shared that she first came to know beki language from a cousin who is fluent in such lingo. "It sounded hilarious and strange so I thought, why not learn the language? It just surprised me that a lot of its words are being adopted nowadays whether male or female, straight or homosexual," she added.

Other Basic Swardspeak Terms:

'Teh - Term of endearment (short term for Ate meaning sister) Alternative word: Ateng, Lola, Ate Wit - means no/none

Alternative word: witchelin, nada, negative Pak - an expression of affirmation Alternative word: true, trulalu, korek, confiiiiirrmm, truth 
Aura - referring to a gimmick

Alternative word: walk

Bet - like

Alternative word: betchina

Chaka - means ugly

Alternative word: Chaka Khan

Rica - means rich

Purita Aragon - means poor

Rampa - to walk

Gandara - means pretty

Alternative word: Gandara Park

Effect - means good looking or nice (a compliment)

Over the years, more and more phrases have been added to the semantic lists of swardspeak/beki language. With the country having more than a hundred different languages and dialects, the people have learned to integrate substantial additions of words from the vernacular of every region. Thus, it's no surprise that swardspeak has been accepted into our vocabulary. If you want to be well-versed in this language, one has to stay sharp, fast-thinking, and witty to catch up quickly. 